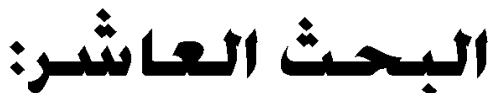

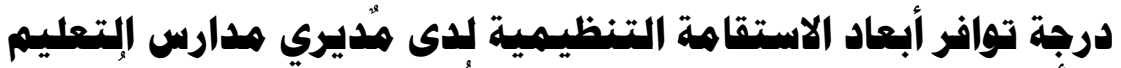

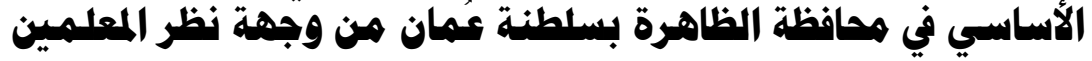

\section{إحقاڤ :}

الباحث / خاصر بن سيف بن سعيد الناصري وزارة التربيت والتعليه سلطنت علئ عمان.

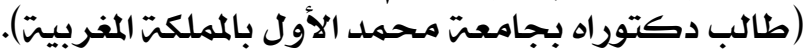

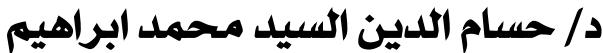

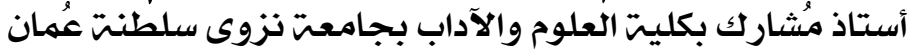





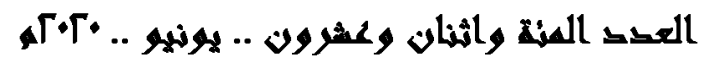

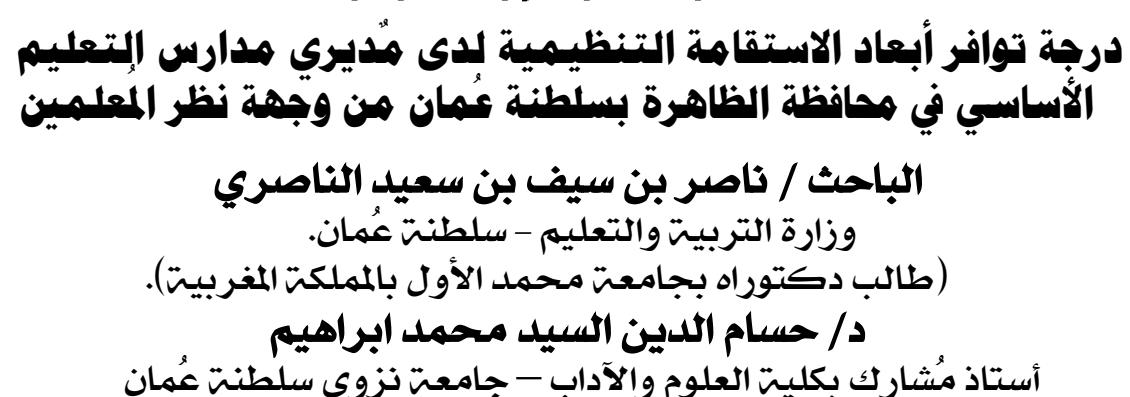

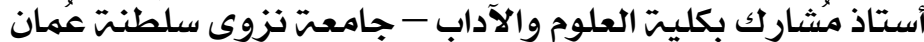

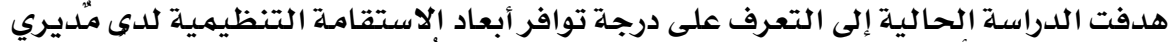

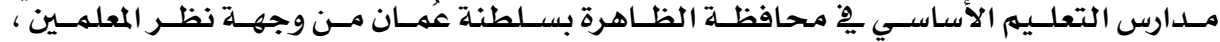

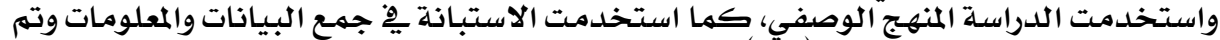

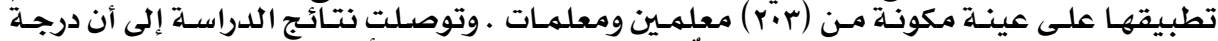

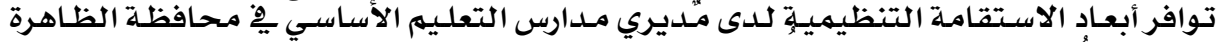

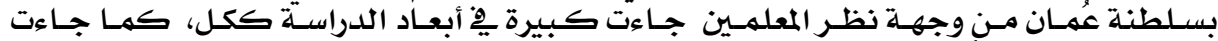

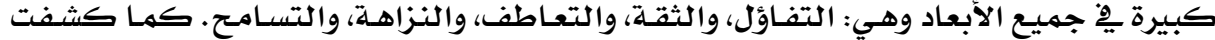

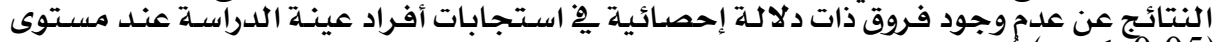

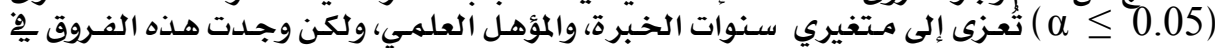

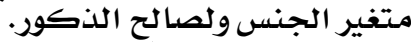

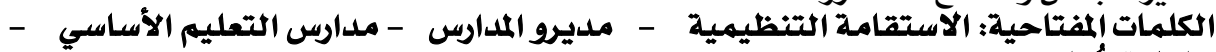
سلطنة عُمان.

The Degree of Availability of Organizational Virtuousness Dimensions for Principals of Basic Education Schools in Al Dhahirah Governorate, Sultanate of Oman from the Viewpoint of Teachers

\section{Abstract}

The current study aimed to identify The degree of availability of organizational Virtuousness dimensions for principals of basic education schools in Al Dhahirah Governorate, Sultanate of Oman from the viewpoint of teachers, study used a descriptive method also used the questionnaire to collect data and information were applied to a sample of (203) teachers. The findings of the study showed The degree of availability of organizational Virtuousness dimensions for principals of basic education schools in $\mathrm{Al}$ Dhahirah Governorate was generally high achieved; They also came high achieved of all dimensions: Optimism, Trust, Compassion, Integrity and Forgiveness. Results also showed that there were no significant differences at $(\alpha \leq 0.05)$ in the study variables which are Years of experience and academic level, but founded significant differences in sex variable and in favor of males. Key Words: Organizational Virtuousness - school principals - Teachersbasic education schools- Sultanate of Oman.

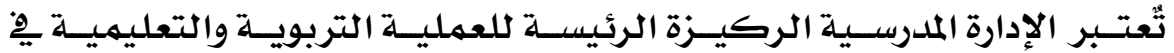

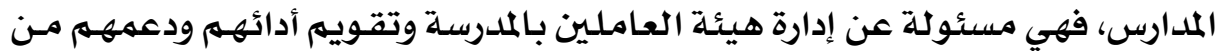

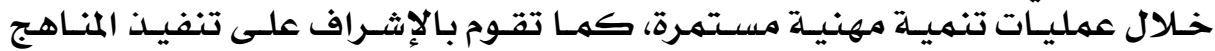




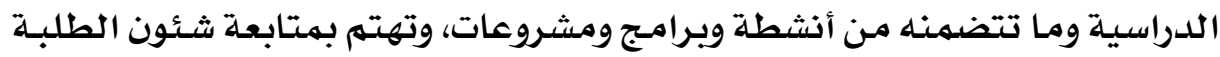

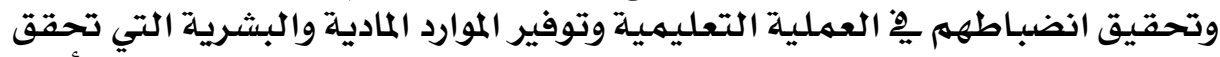

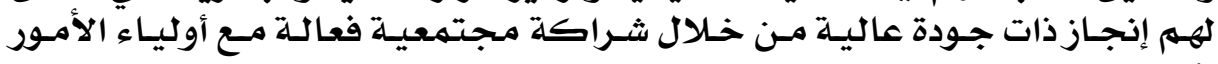
وأعضاء المجتمـع المحلي.

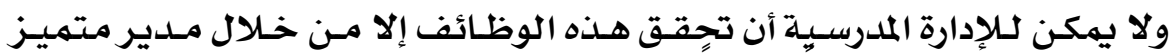

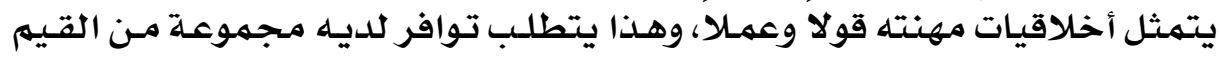

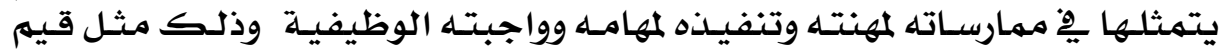

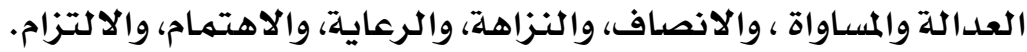

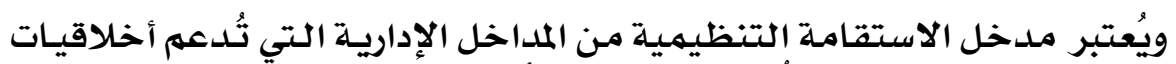

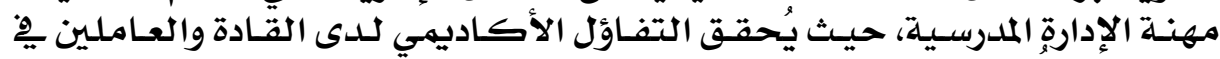

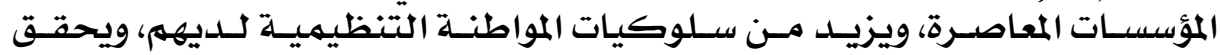

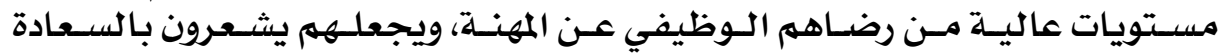

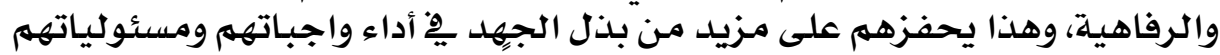

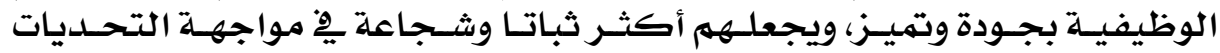

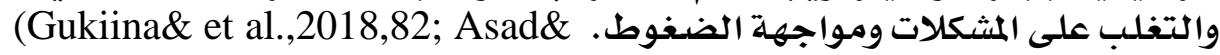
et al., 2017, 37-38 )

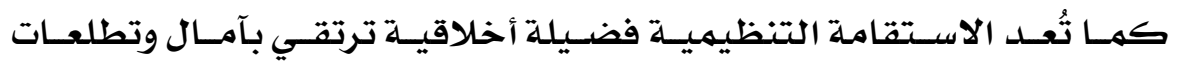

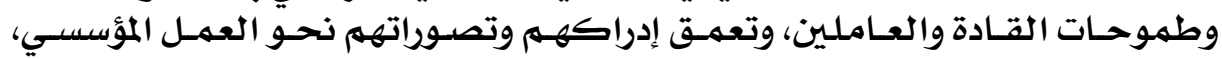

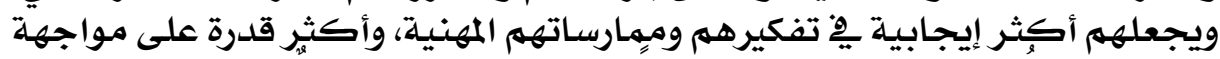

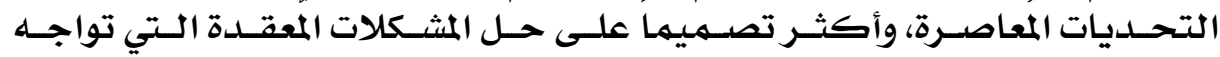
المؤسسة.

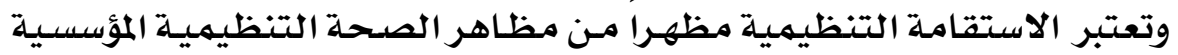

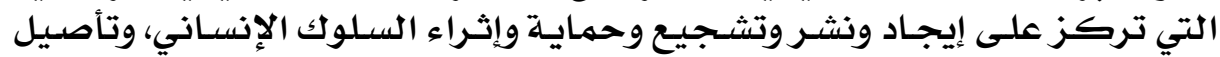

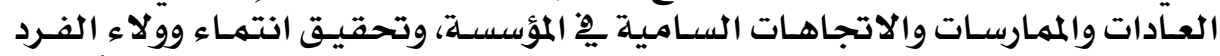

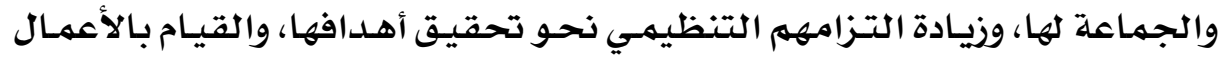

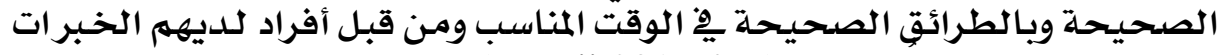
والكفاءات والمهارات المتميزة المبحة ' Ravaji,2016,497)

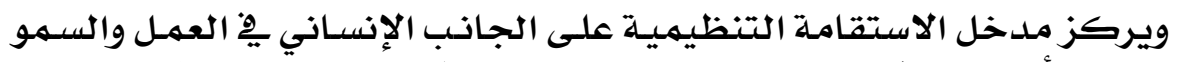

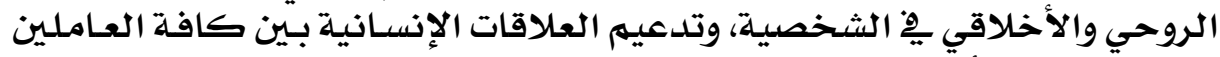

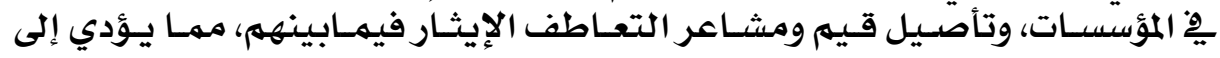

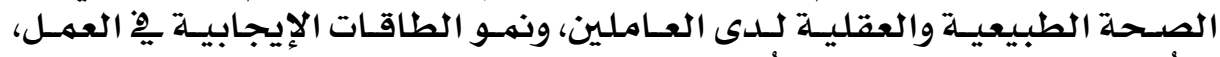

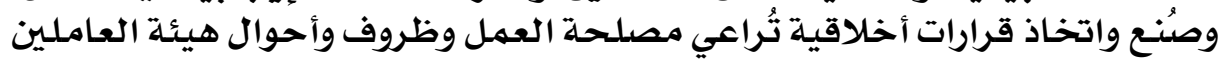

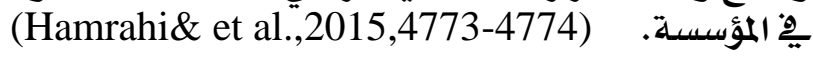

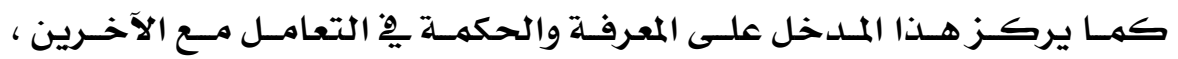

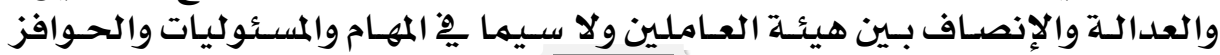

\section{YY $\varepsilon$}




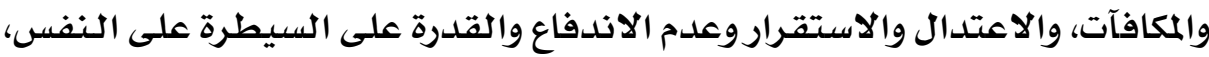

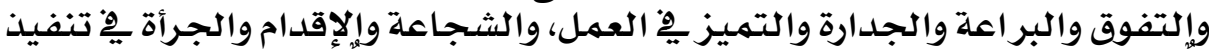

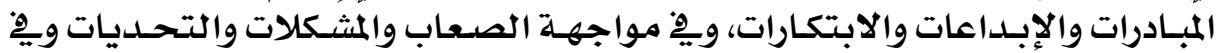
اتخاذ القرارات. (Hamrahi\& et al.,2017,21)

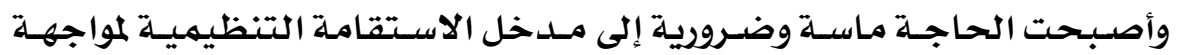

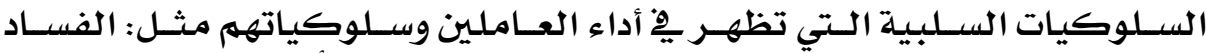

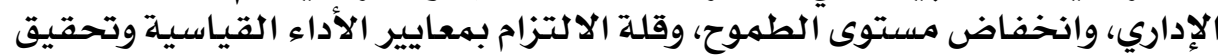

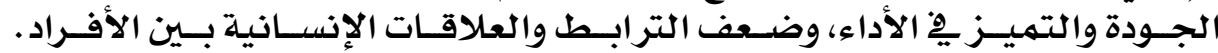

(Pereira.,2014,40)

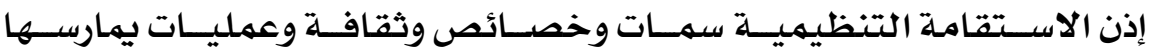

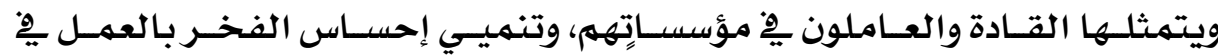

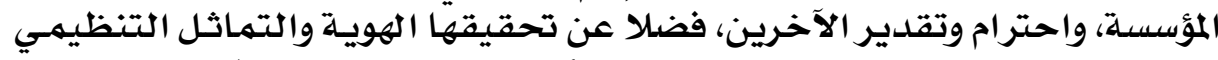

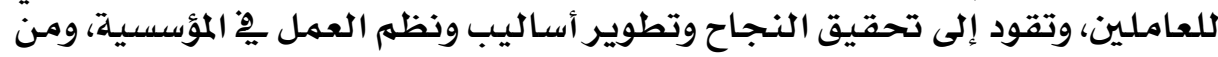

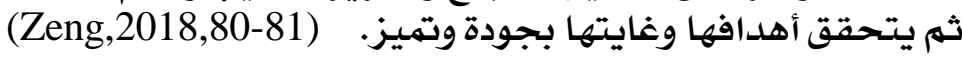

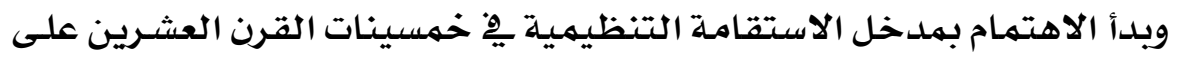

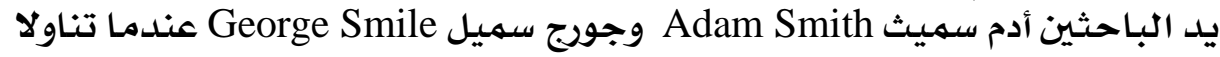

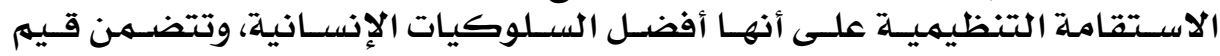

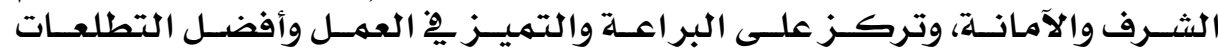

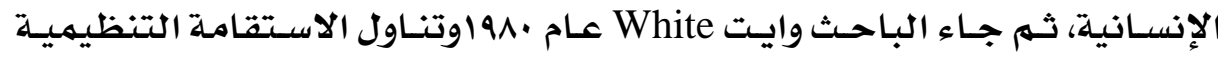

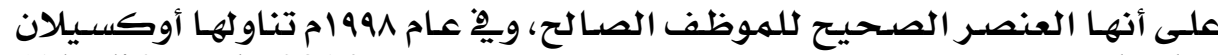

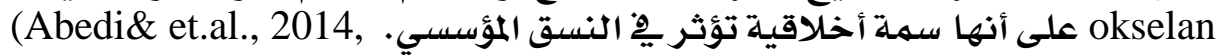

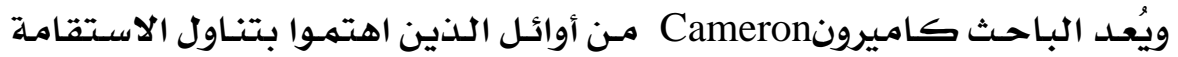

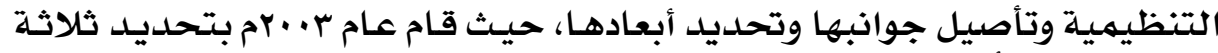

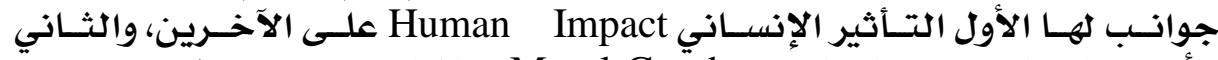

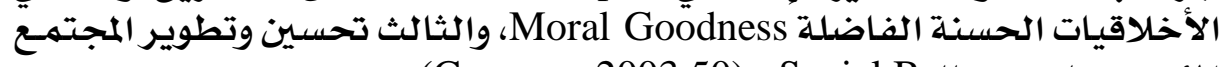
المؤسسي Social Betterment

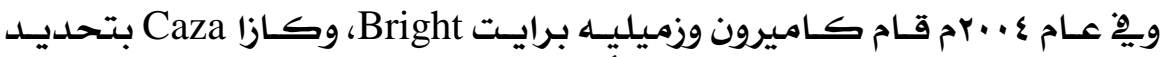

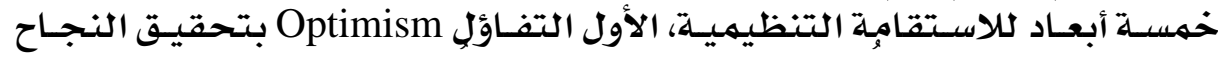

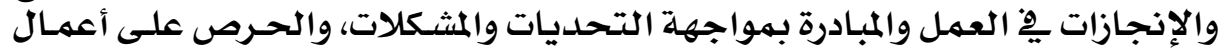

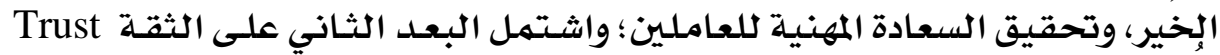

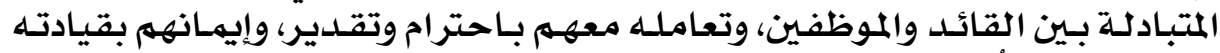

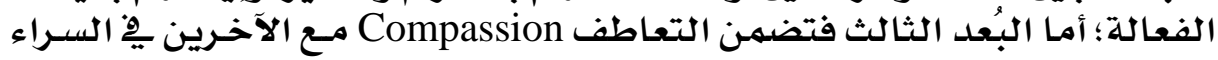

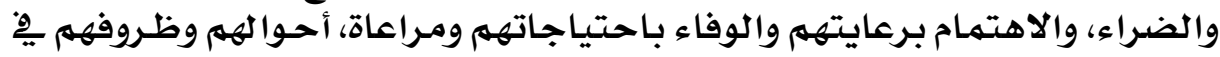

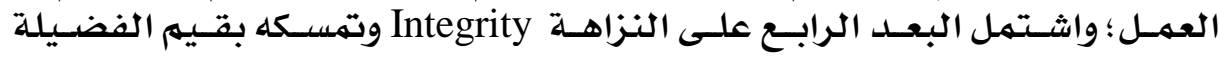




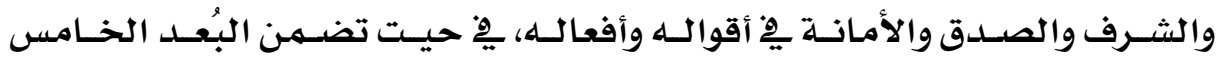

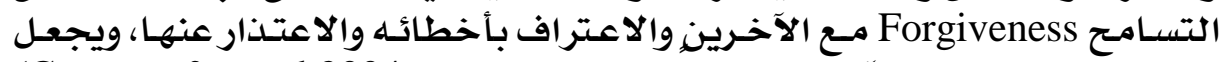

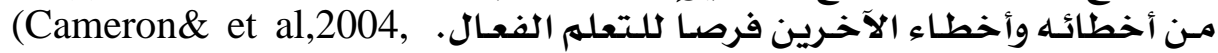
13-14; Meyer, 2018, 245)

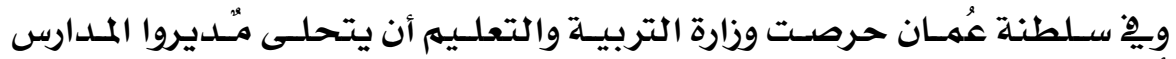

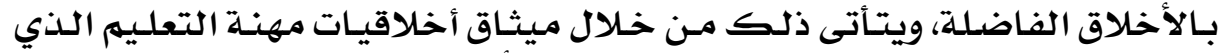

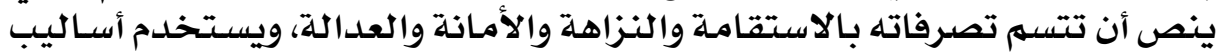

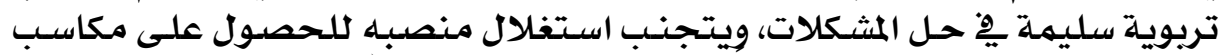

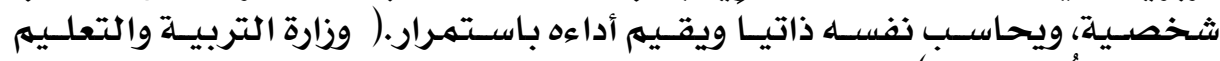

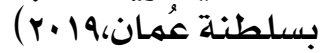

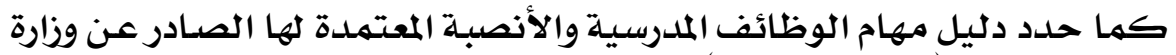

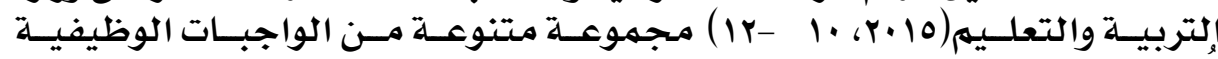

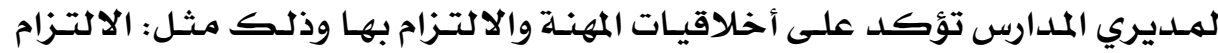

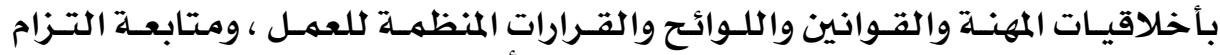

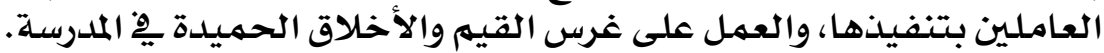

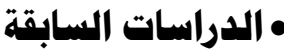

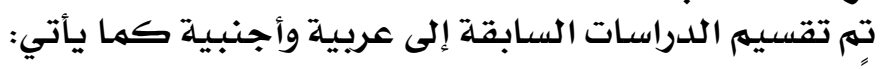

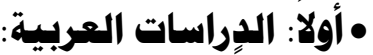

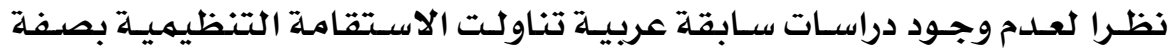

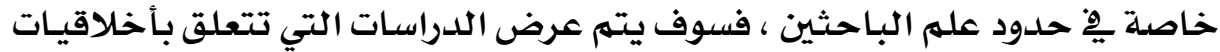

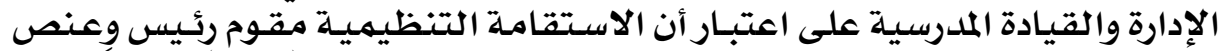

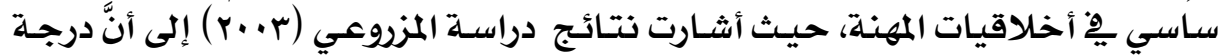

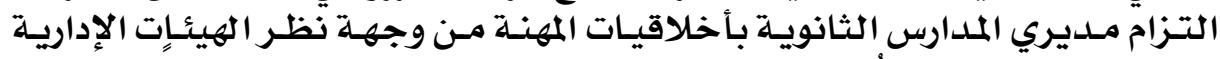

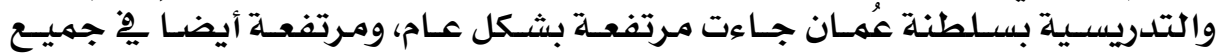

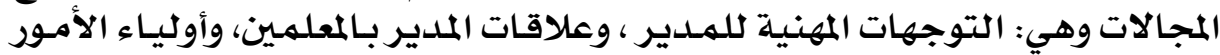

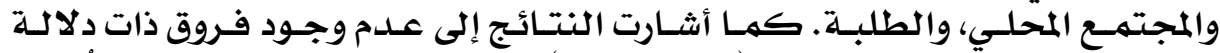

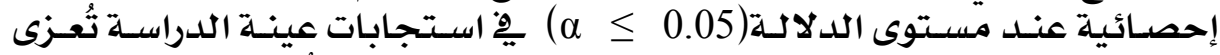

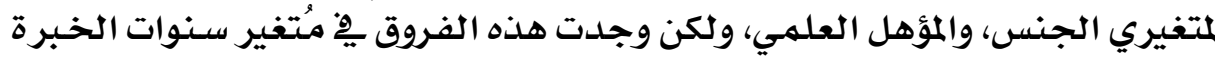
ولصالح الخبرة الطويلة. والمولئ.

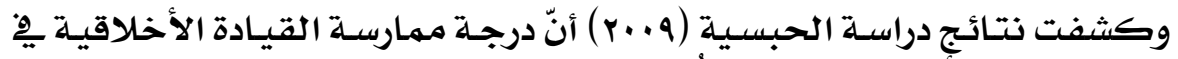

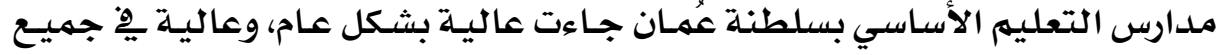

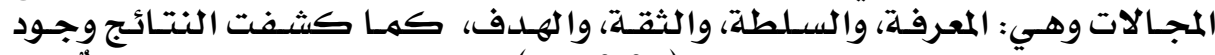

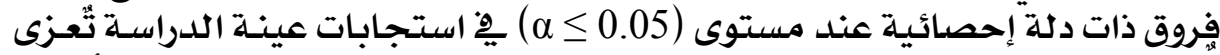

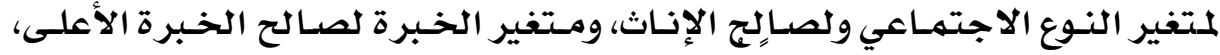

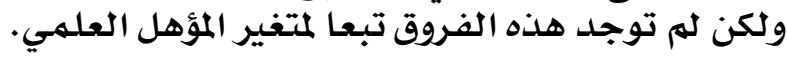




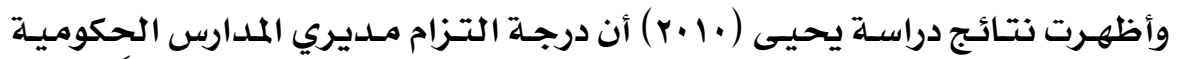

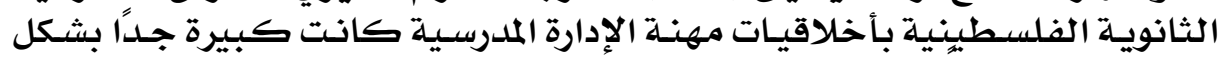

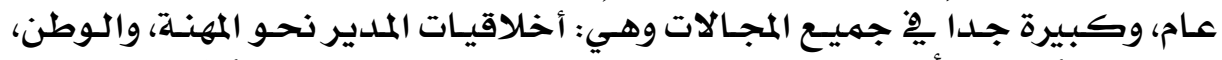

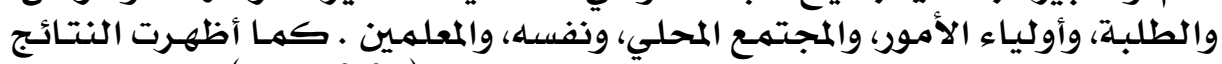

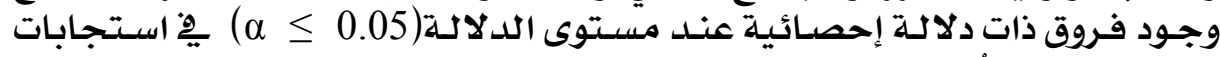

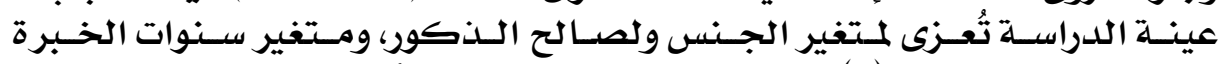

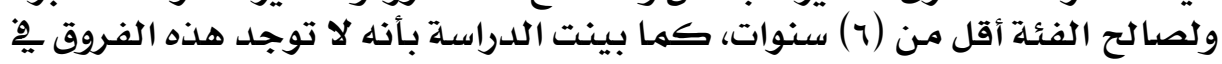
متغير المؤهل العلهي.

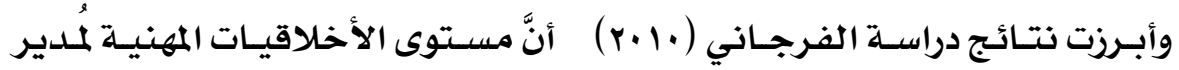

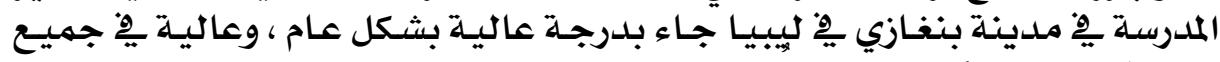

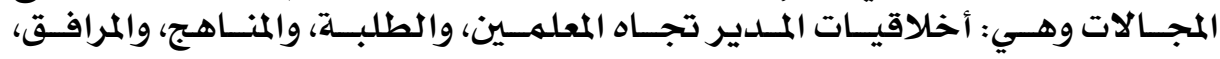
والتجهيزات المدرسية، والمجتيستهـع المحلي.

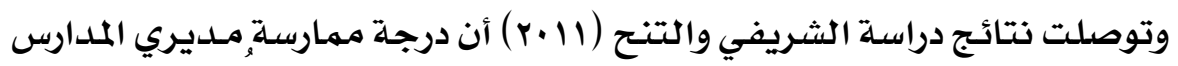

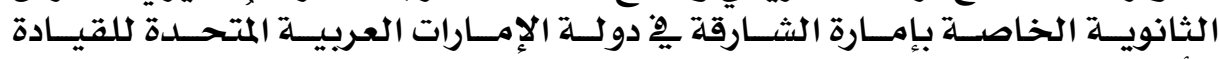

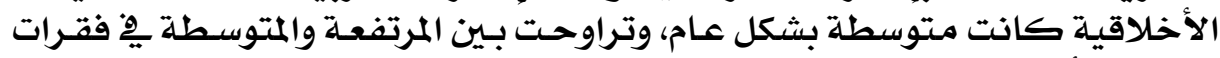
القيادة الأخلاقيـة.

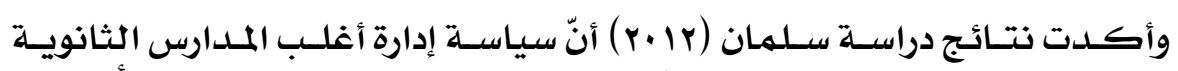

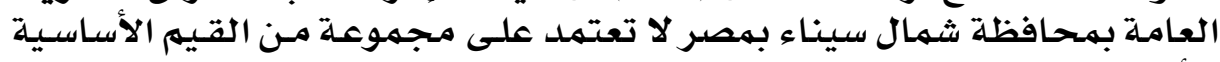

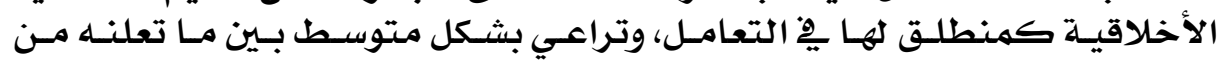
أهداف وما تطبقهـ.

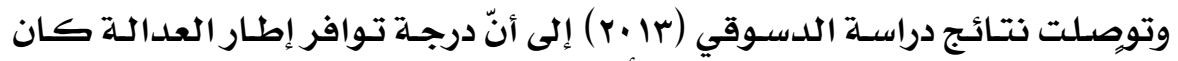

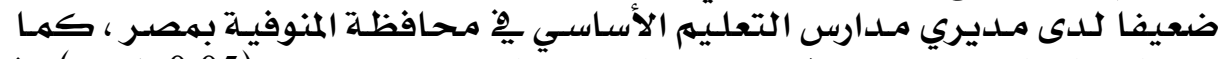

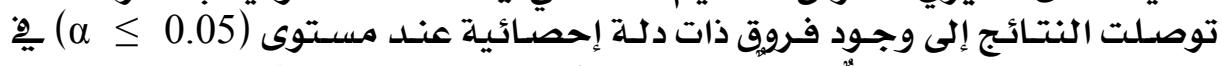

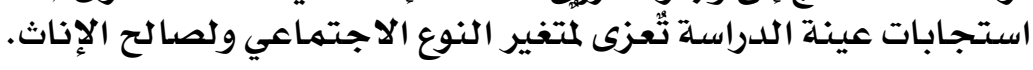

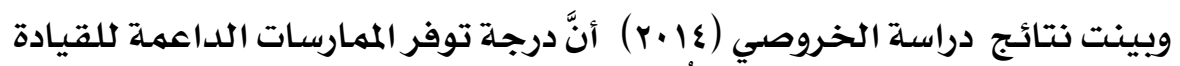

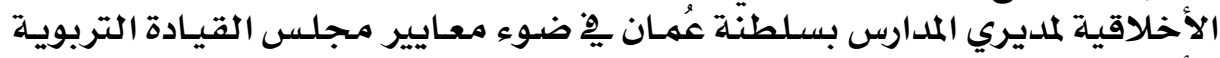

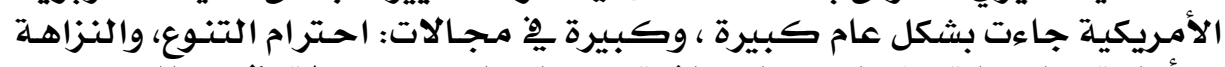

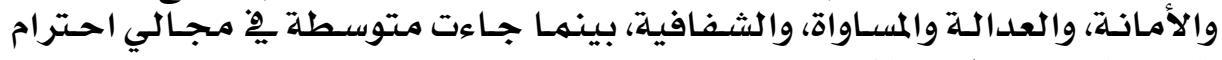
القيهم الديهقراطية والثقة والثة.

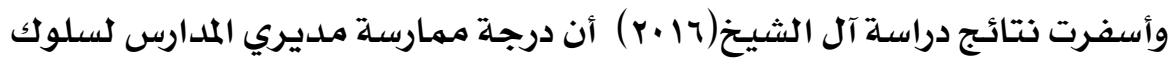

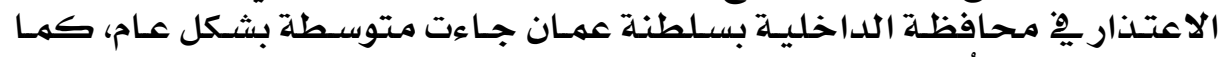

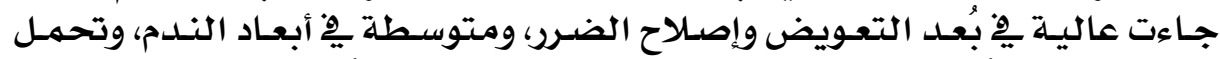

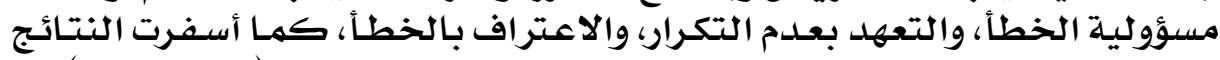

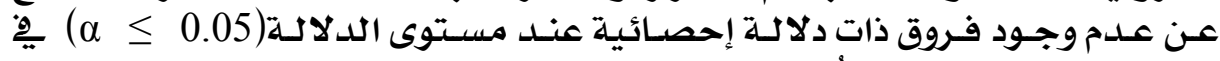

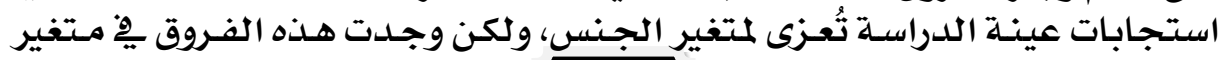




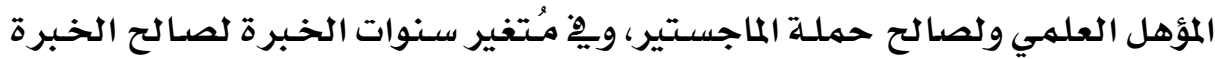
أقل من خمس العسلعي ولهنوات.

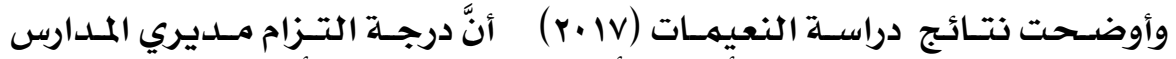

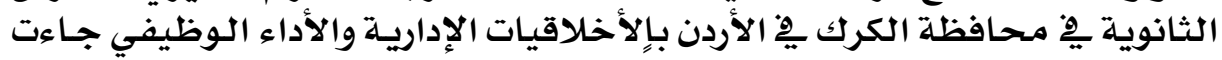

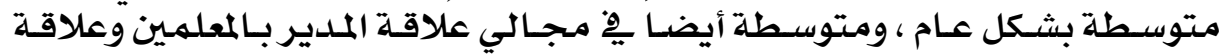

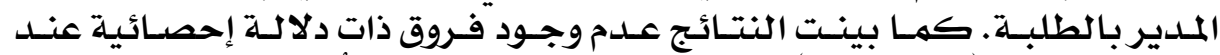

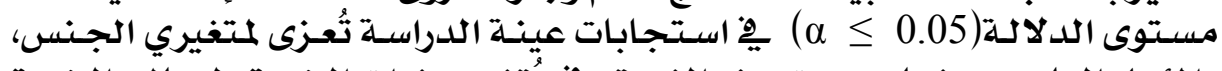

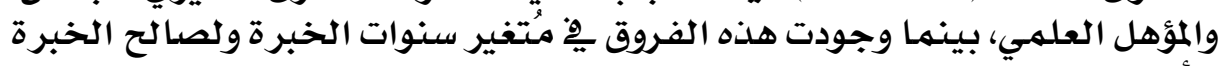
الأعلى. والمول.

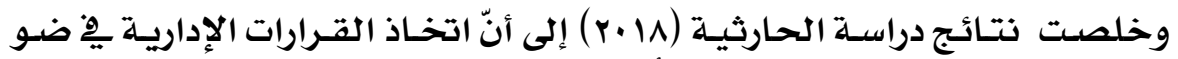

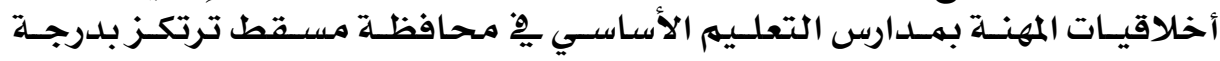

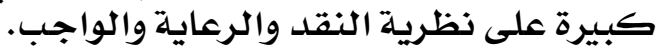

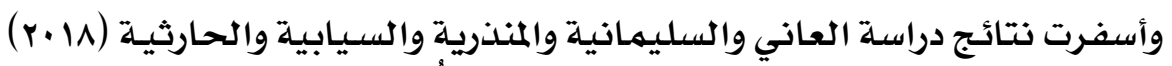

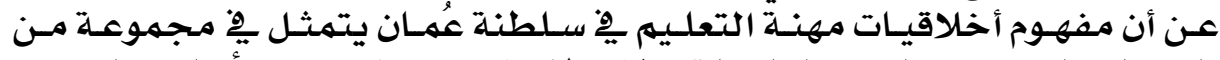

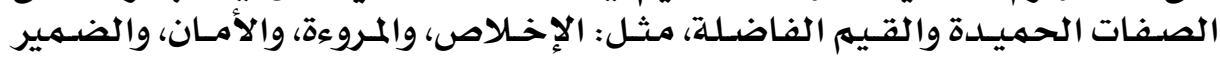
المهني.

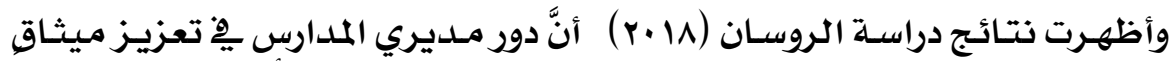

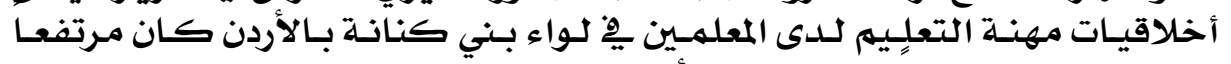

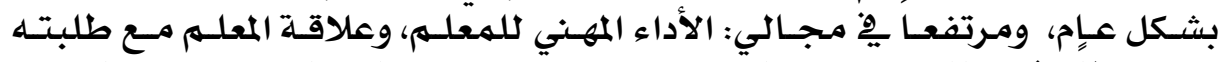

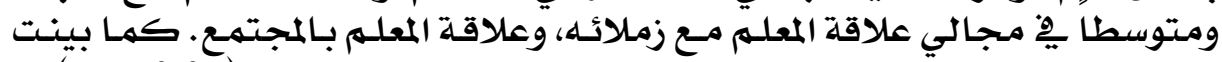

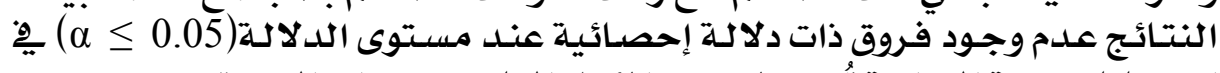

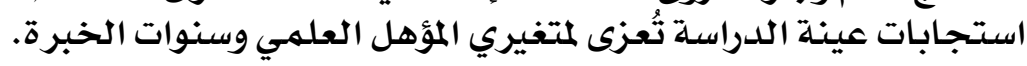

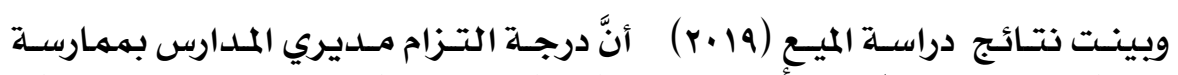

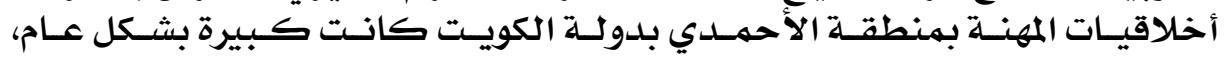

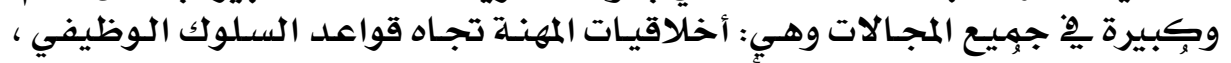

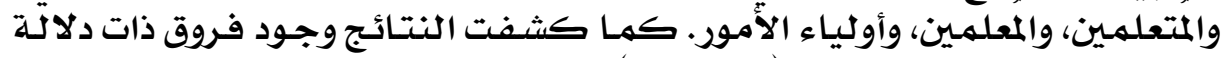

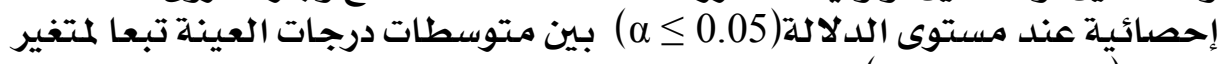

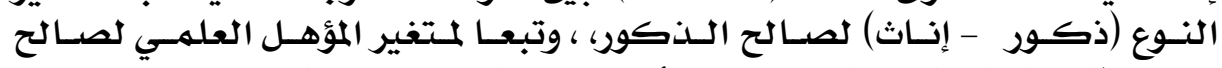

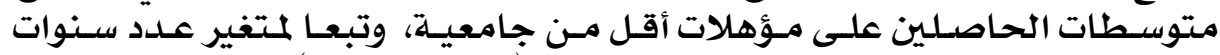

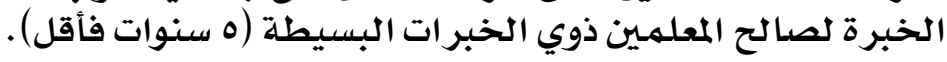

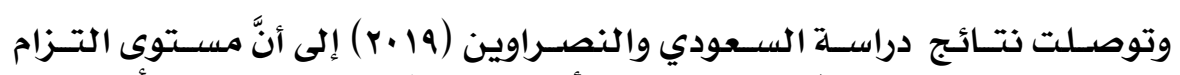

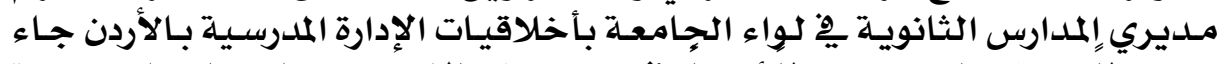

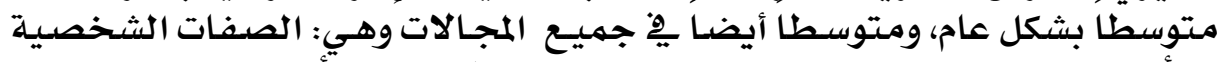

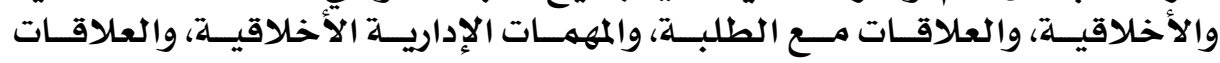




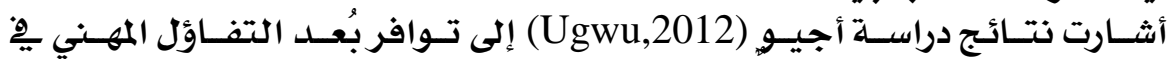

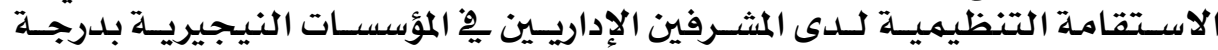

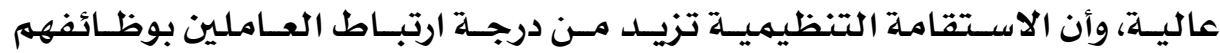

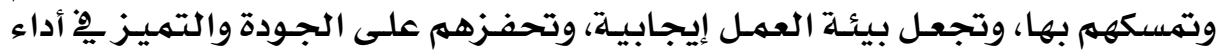

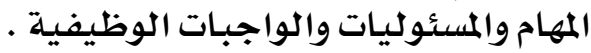

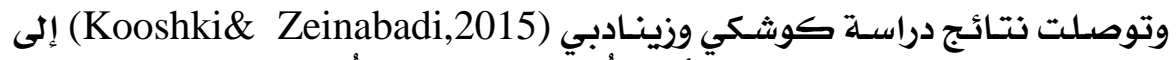

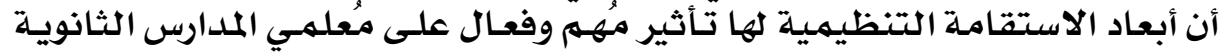

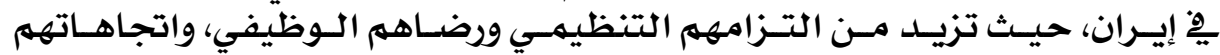
الإيجابية نحو المهنية.

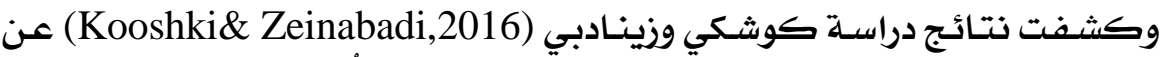

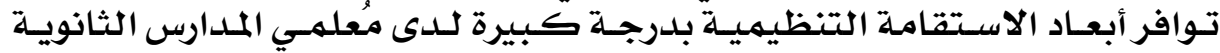

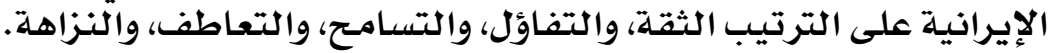

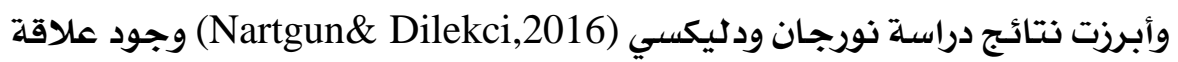

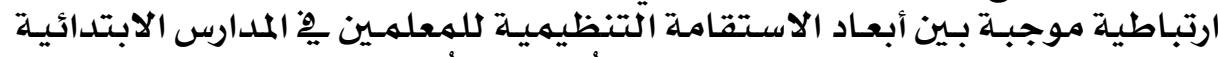

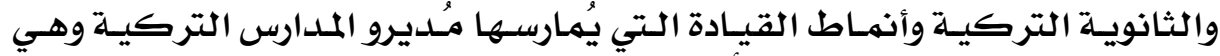

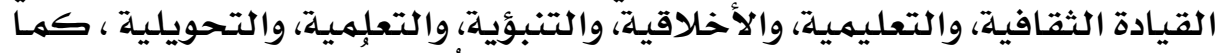

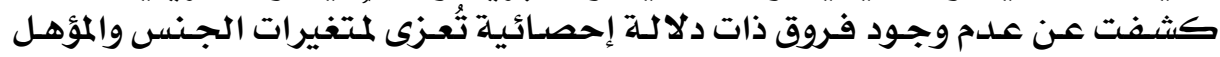

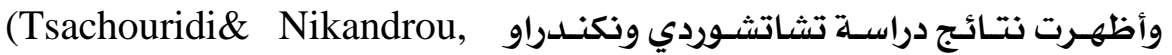

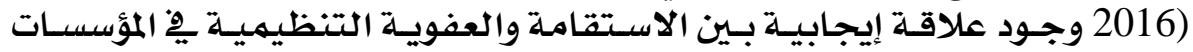

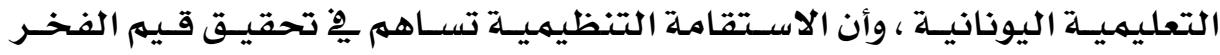

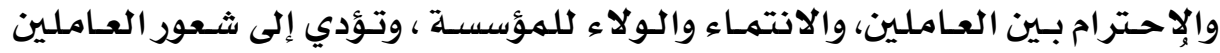

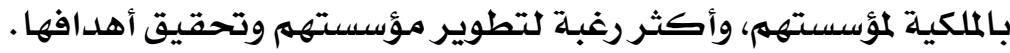

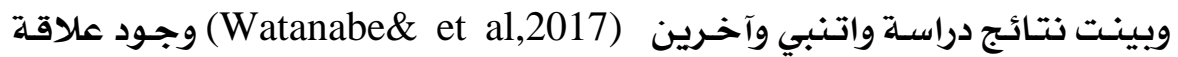

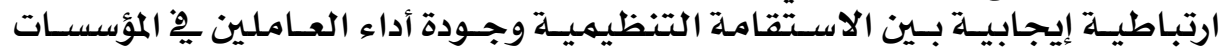

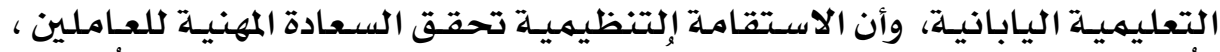

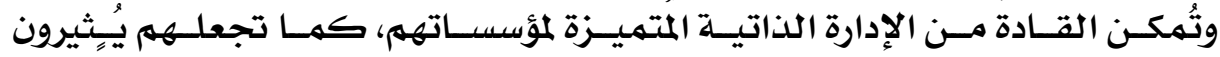

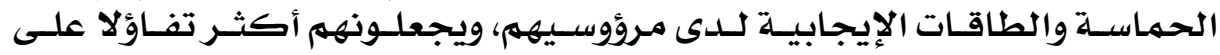

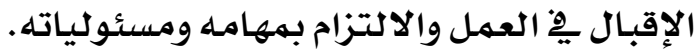

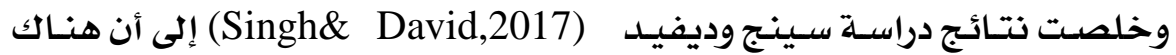

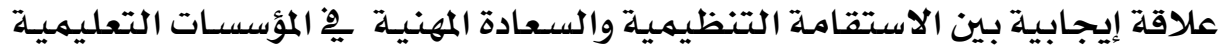

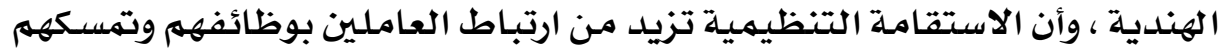

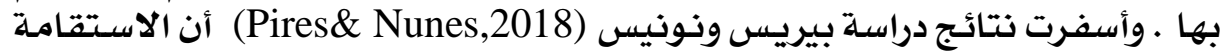

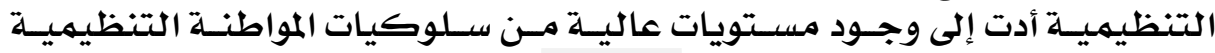

\section{rra}




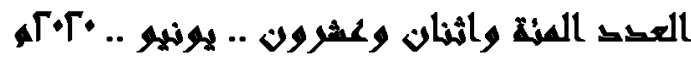

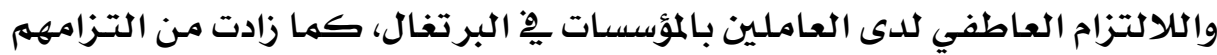

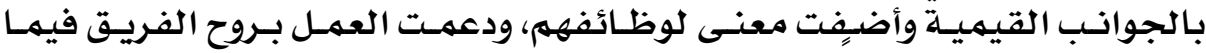

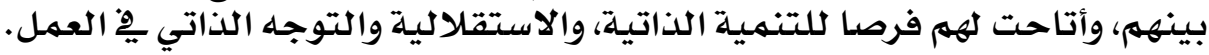

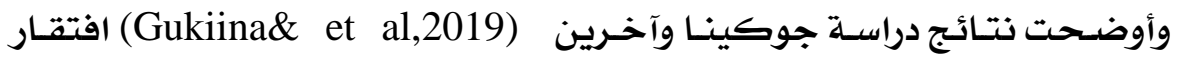

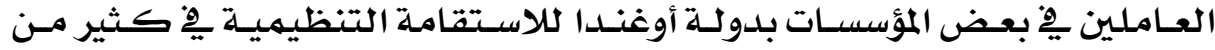

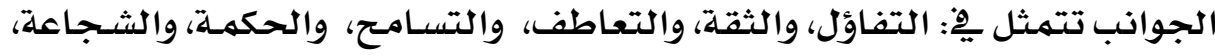

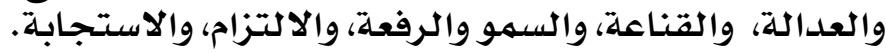

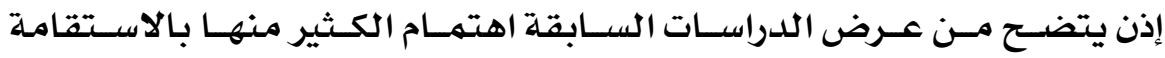

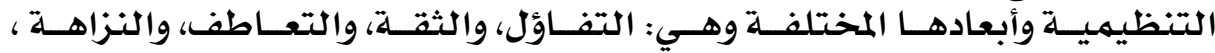

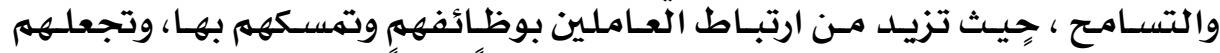

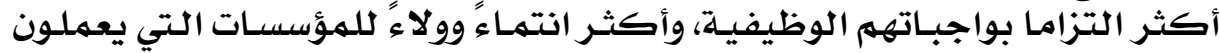

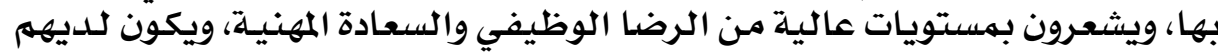

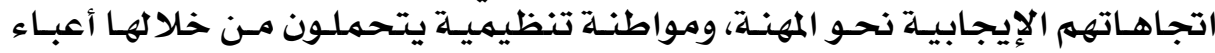
عمل إضـافيـة.

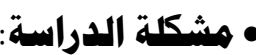

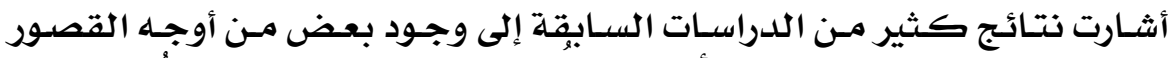

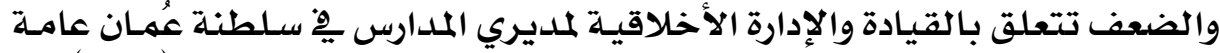

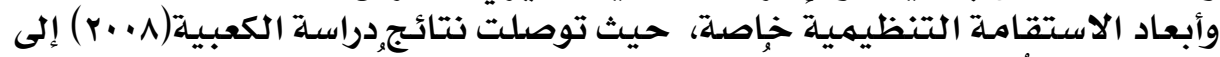

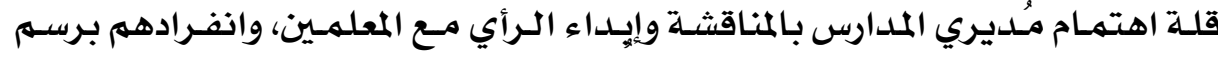

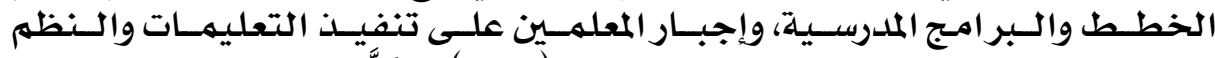

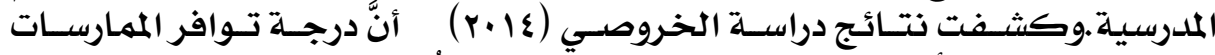

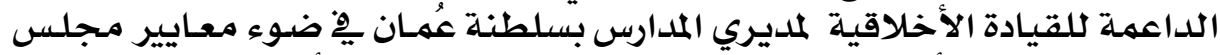

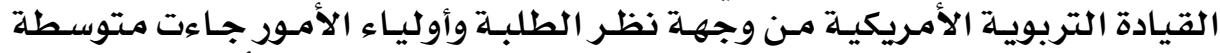

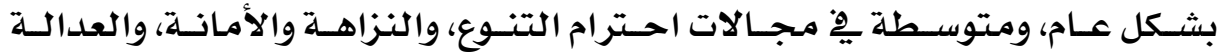

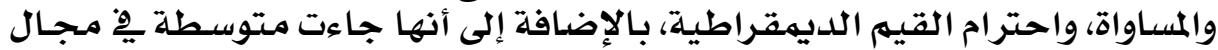

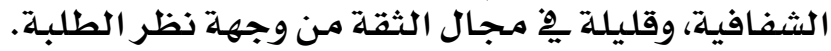

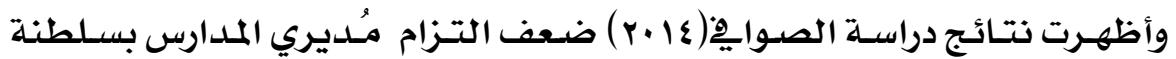

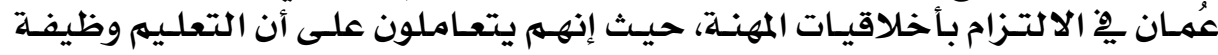

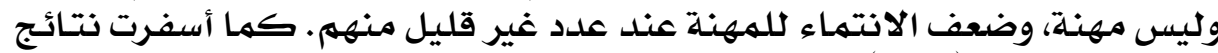

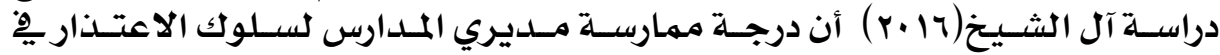

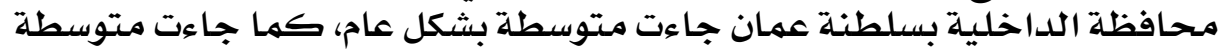

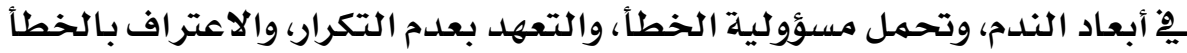
وتأسيساً على ما سبق يمكن أن تتحدد مشكلة الدراسة يِّا التساؤلين الآتيين:

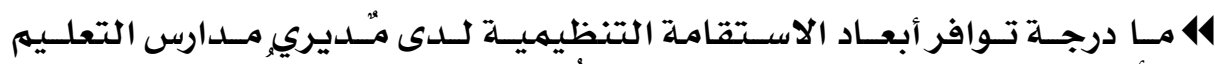

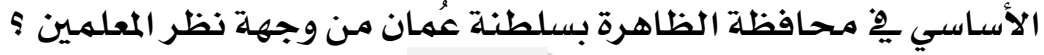




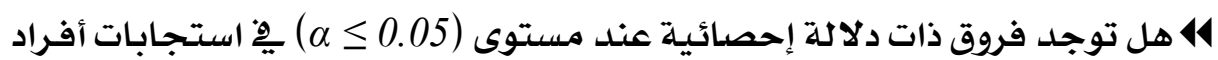

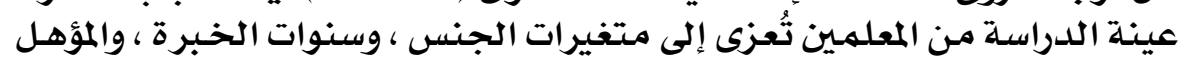

$$
\begin{aligned}
& \text { العلـهي } \\
& \text { •أهداف الثراسة } \\
& \text { هدفت هذه الدراسـة إلى : الى }
\end{aligned}
$$

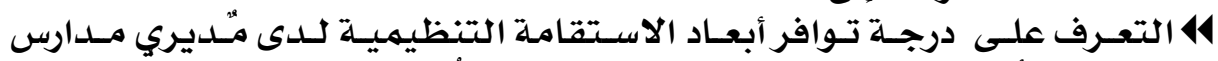

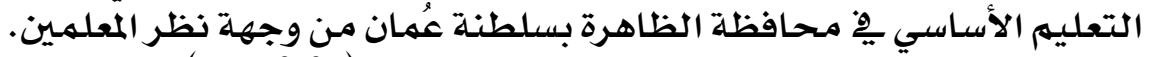

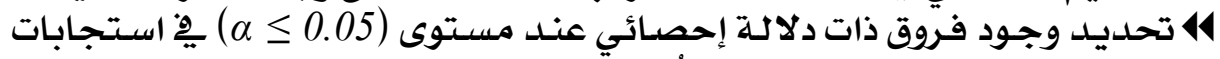

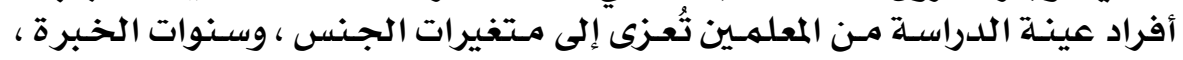

$$
\text { •أهمية والمؤهل العلدية أدراسية : }
$$

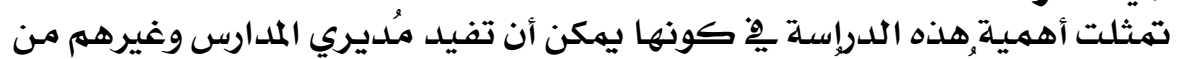

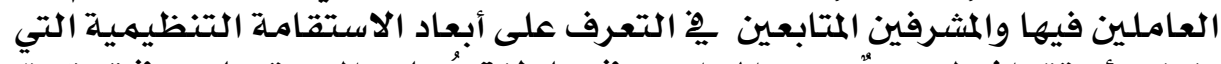

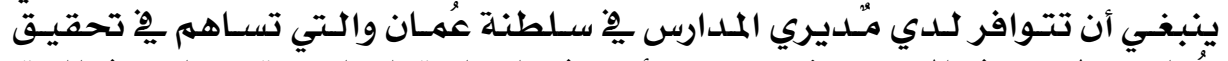

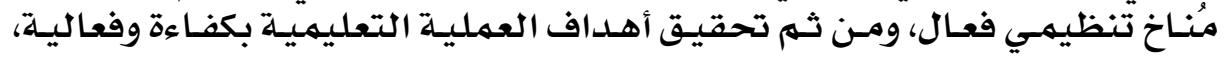

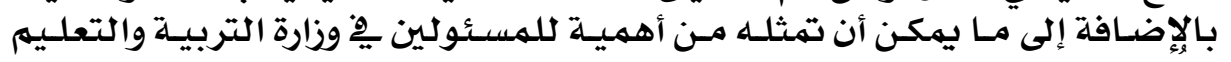

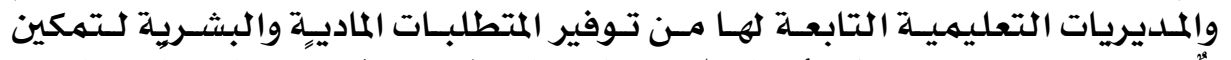

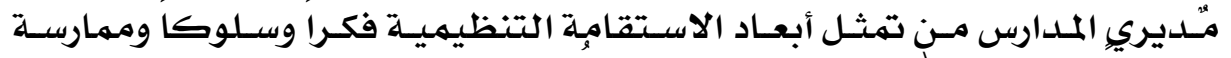

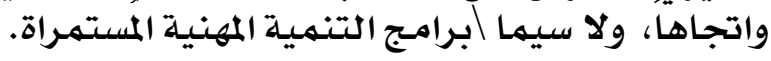
• هدود الدراسةة:

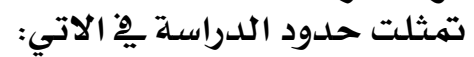

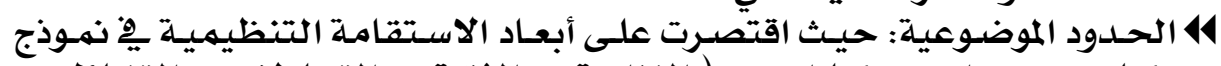

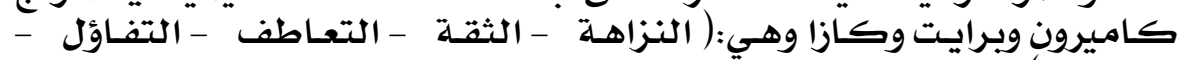

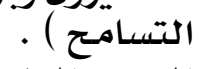

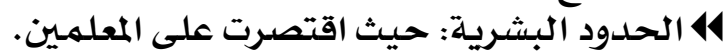

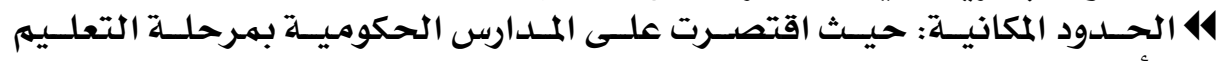

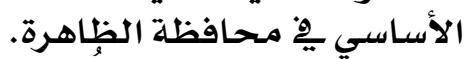

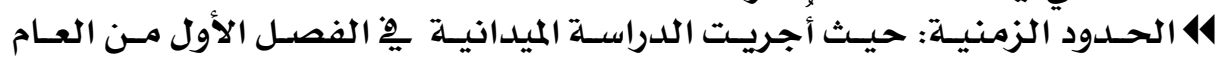

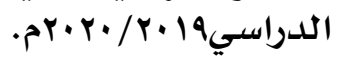

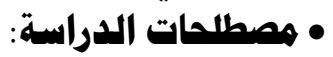

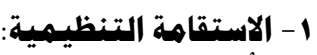

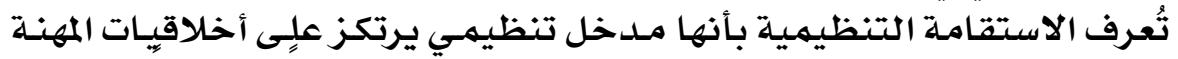

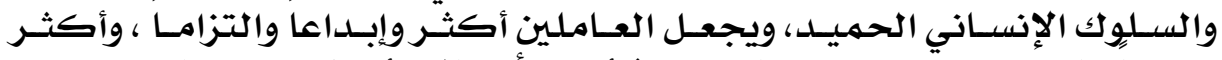

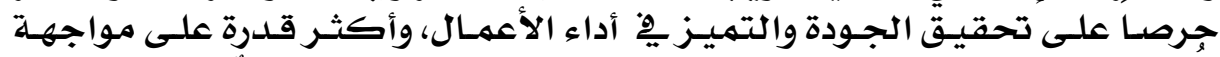

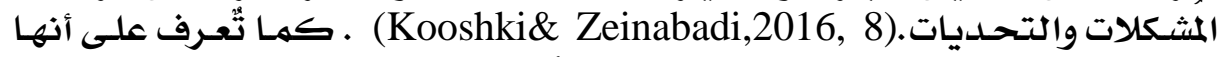

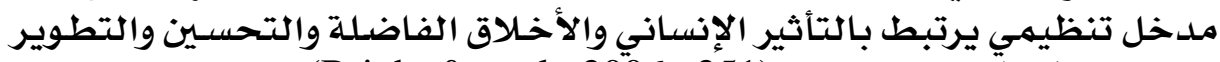

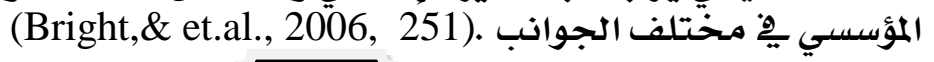




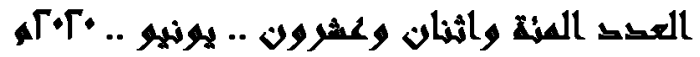

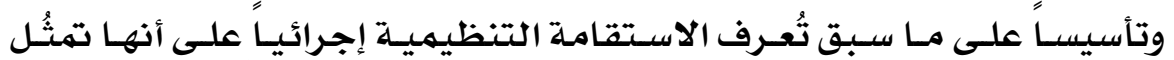

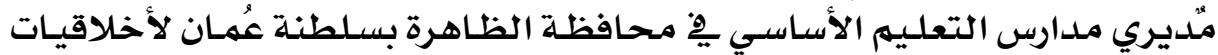

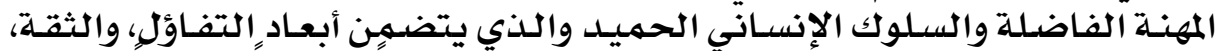

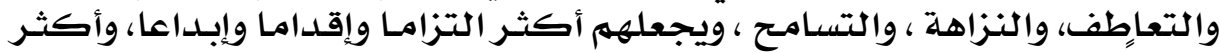

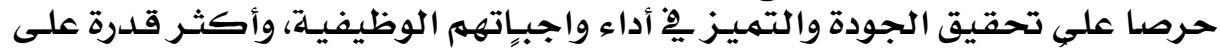

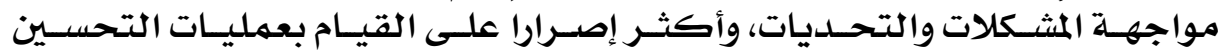

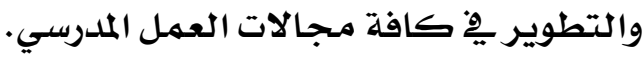

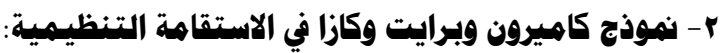

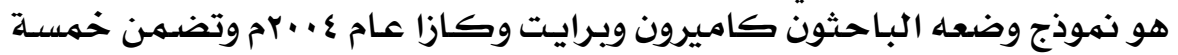

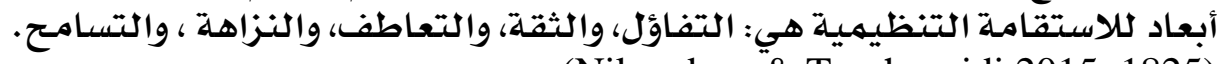

(Nikandrou,\& Tsachouridi,2015, 1825)

$$
\begin{aligned}
& \text { • الإجراءات المنهمية لإلدراسة: } \\
& \text { وتتمثل تلك الإجراءاءات الإنهاتئ: فيما يأتي: }
\end{aligned}
$$

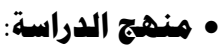

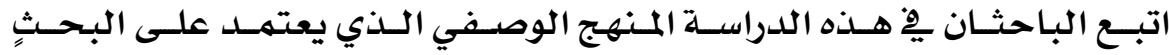

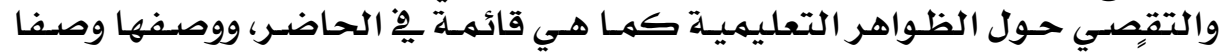

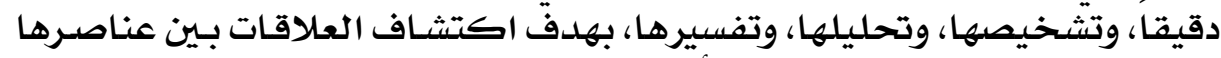

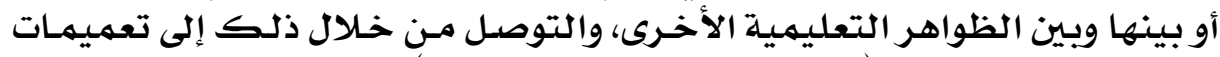

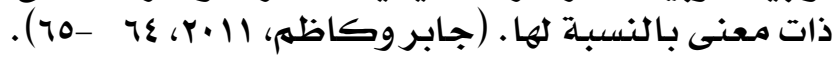

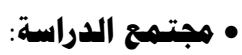

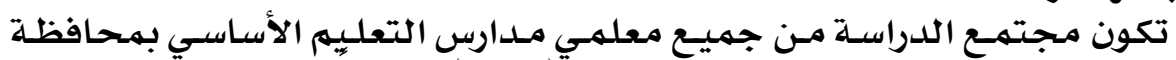

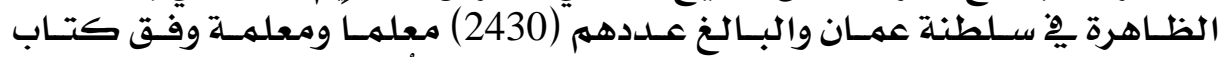

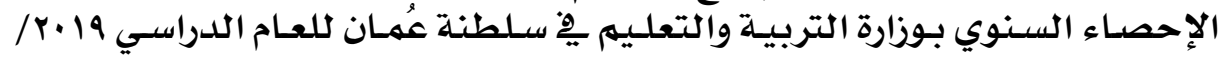
. r.r.

\section{• (عينة الدراسة:}

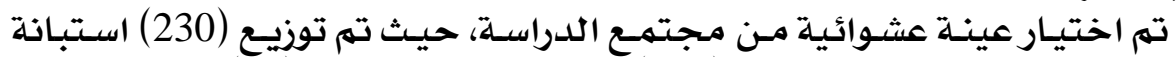

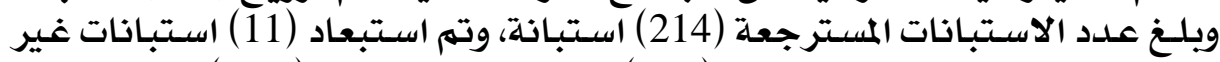

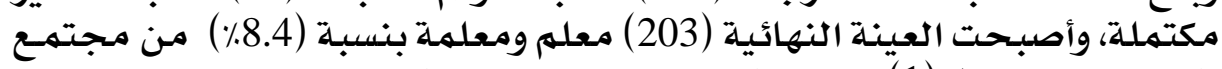

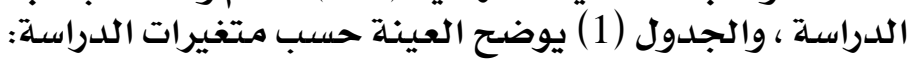

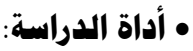

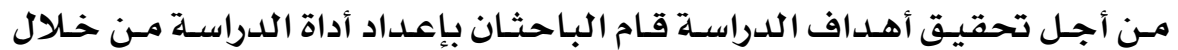

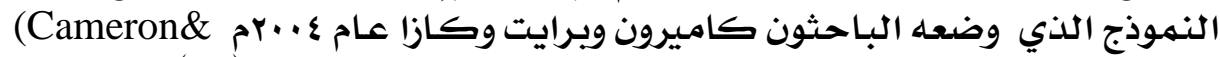

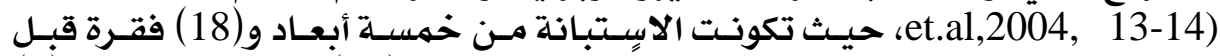

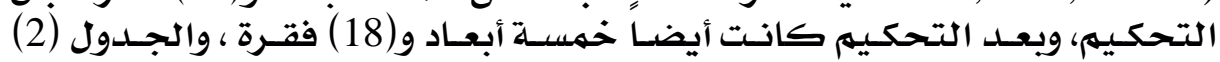
يوضح الأبعاد الخمسة وعدي التحكيه فترات كل منها ونسبتها المئوية. 


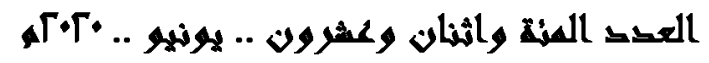

جـدول (1): توزيع عينت الدراستحسب المتفيرات الديموفرافيت

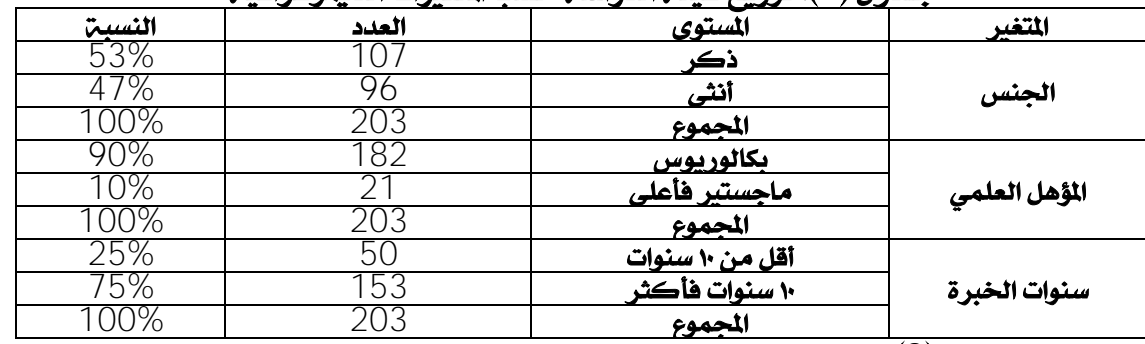

جـدول (2): توزيع أبعاد الدراستستوفقرات كل منها والنسب المئويتش للفقرات

\begin{tabular}{|c|c|c|c|}
\hline النسبت المثويتة (\%) & عدد الفقرات & الأبعاد & \\
\hline $22.2 \%$ & 4 & التفاؤل & 1 \\
\hline $22,2 \%$ & 4 & الثقتة & 2 \\
\hline $16.7 \%$ & 3 & التعاطف & 3 \\
\hline $22,2 \%$ & 4 & الثزاهت & 4 \\
\hline $16.7 \%$ & 3 & التسامح & 5 \\
\hline $100 \%$ & 18 & المجموع & \\
\hline
\end{tabular}

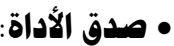

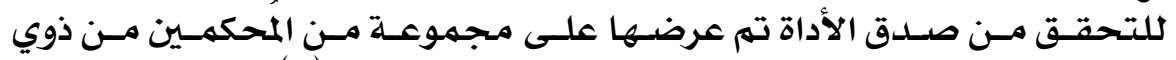

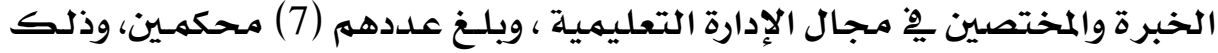

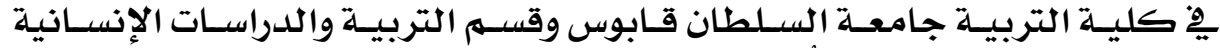

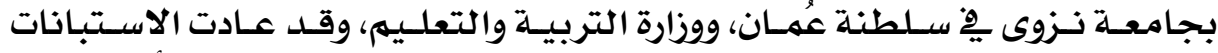

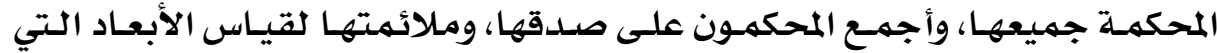

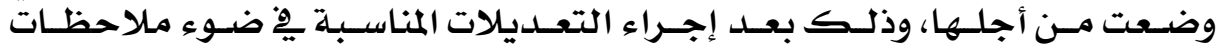
المحكمـين وتوجيهاتهم.

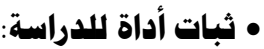

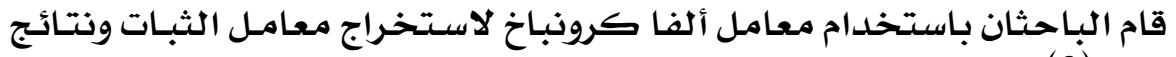

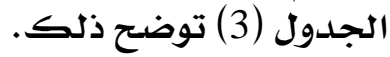
جدول (3): معاملات الثبات تبعاً لأبعاد الدراستة

\begin{tabular}{|c|c|c|c|}
\hline معامل الثيات & عدد ألفقرات & الأبعاد & م \\
\hline .907 & 4 & التفاؤل & 1 \\
\hline .85 & 4 & الثقة & 2 \\
\hline .86 & 3 & التعاطف & 3 \\
\hline .86 & 4 & النزاهتة & 4 \\
\hline .86 & 3 & التسامح & 5 \\
\hline .89 & 18 & & الثات الكار \\
\hline
\end{tabular}

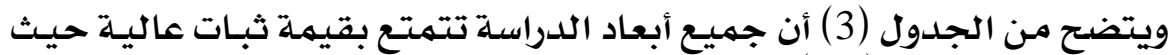

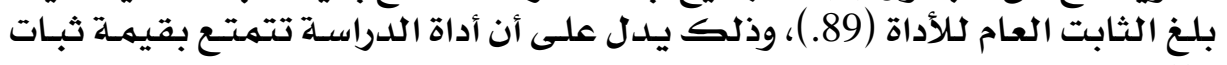
عالية.

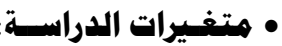

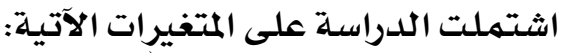
41 الجنس، وله مستويان هما : (ذلكر - أنثى) . 


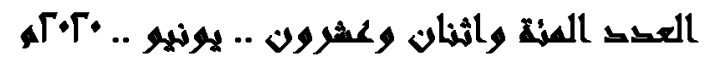

14 المؤهل العلهي وله مستويان: (بكالوريوس - ماجستير فأعلى) .

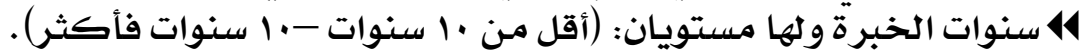

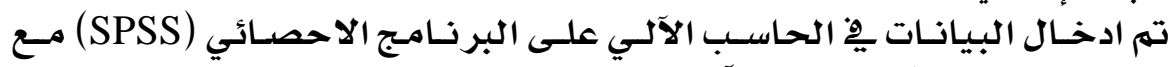

استخدام المعالجات الإحيات الحصائية الآتية:

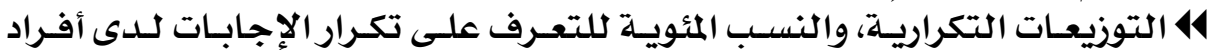
عينة الدراستة.

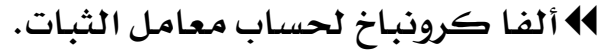

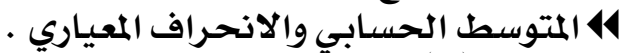

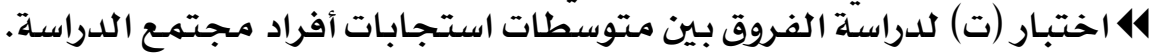
• نتائج الدراسية:

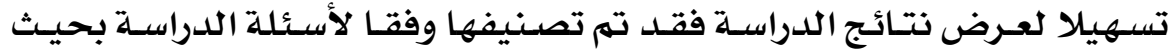

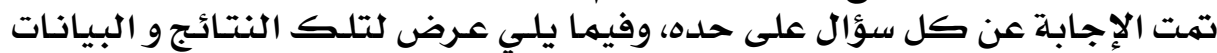

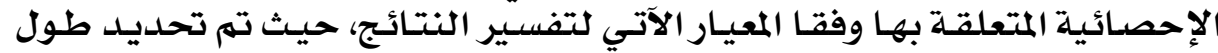

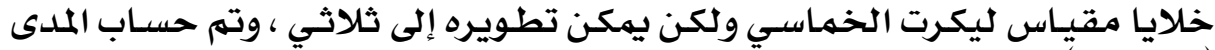

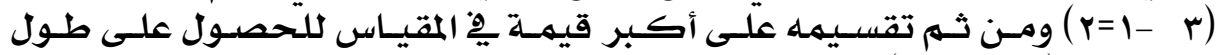

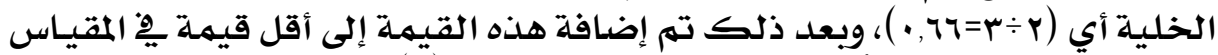

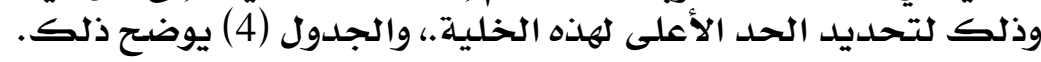

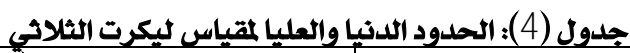

\begin{tabular}{|c|c|}
\hline المتوسط الحسابي(طول الخليت) & درجت الموافقتة \\
\hline من 1.66 إلى اقل من 1.66 من 2.33 & قليلة \\
\hline من 1.66 إلى ألى من 2.33 من 2.33 & متوسطة \\
\hline
\end{tabular}

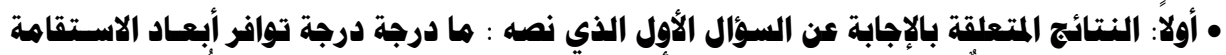

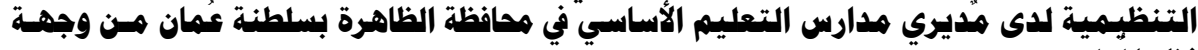

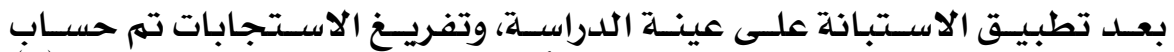

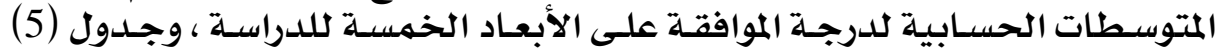
أدناه يوضتح ذلك.

جدول (5):المتوسطات الحسابيت والانحرافات المعياريت لأبعاد الدراست الأنمان

\begin{tabular}{|c|c|c|c|c|c|}
\hline اللدرجة & الانحراف & المتوسط & الأبعاد & الرتبتة & $p$ \\
\hline عالية & 39 & $\frac{2.57}{2.57}$ & التفاؤل & 2 & 1 \\
\hline عالية & .55 & 2.38 & الثقن & 5 & $\overline{2}$ \\
\hline عالية & .56 & 2.54 & التعاطف & 3 & 3 \\
\hline عالية & .48 & 2.68 & النزاهت & 1 & 4 \\
\hline عاليتي & .57 & 2.39 & التسامح & 4 & 5 \\
\hline عالية & .51 & 2.51 & الكلاd & & \\
\hline
\end{tabular}

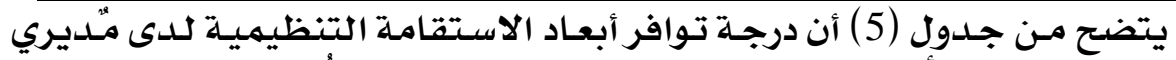

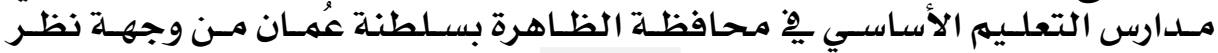




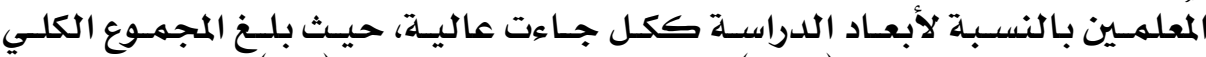

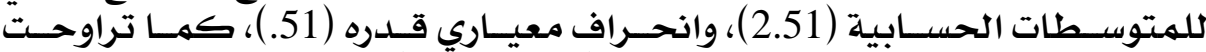

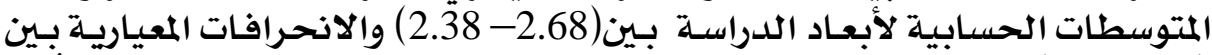

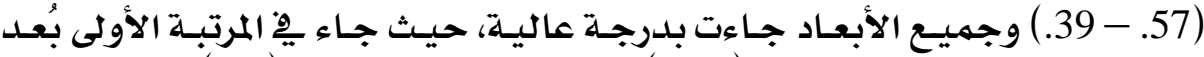

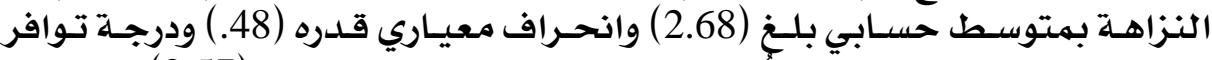

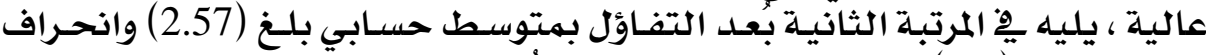

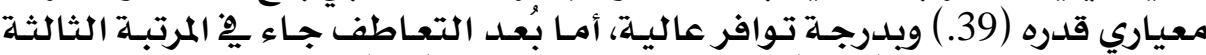

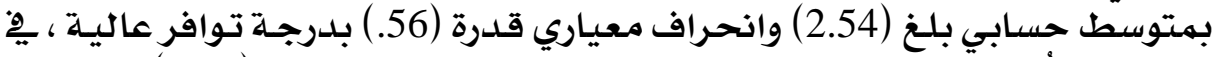

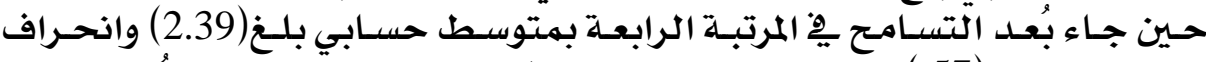

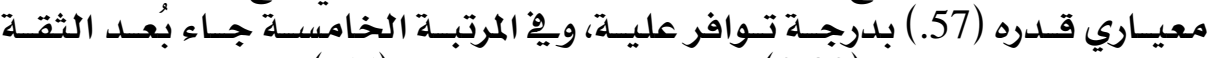

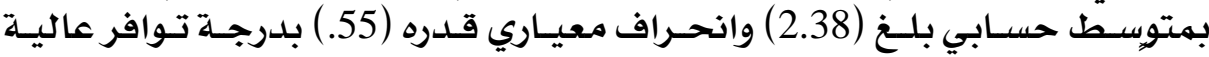
أيضا.

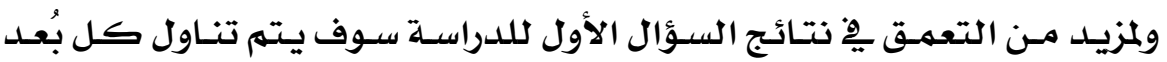
على حده وذلك كمند التها يأتي:

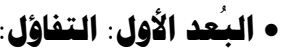

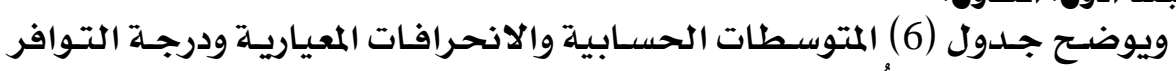

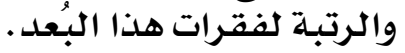
جـدول (6): المتوسطات الحسابيتّوالانحرافات المعياريتشودرجت التوافر والرتبتَ لفقرات بُعد التفاؤل

\begin{tabular}{|c|c|c|c|c|c|}
\hline 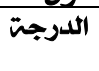 & الانحراف & الحسابط & الفقرة & الرتبتة & p \\
\hline عاليت & .48 & 2.65 & 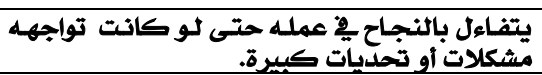 & 2 & 1 \\
\hline عالية & .51 & 2.71 & 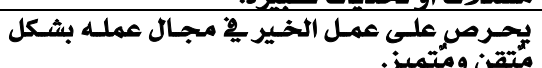 & 1 & 2 \\
\hline عاليتة & .65 & 2.39 & يهتم بتحقيق السعادة المهنيت للعاملين بالملدرستة. & 4 & 3 \\
\hline عاليتة & .58 & 2.51 & ألعمليط بشكل فعالي. بين أداءه المهني وأهداف وغايات & 3 & 4 \\
\hline عاليت & .39 & 2.57 & المجموع الكلي & & \\
\hline
\end{tabular}

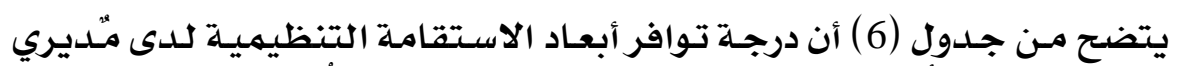

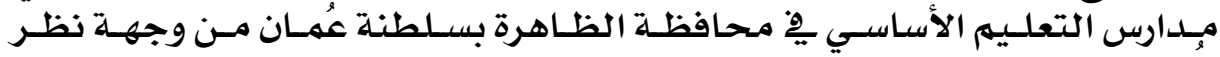

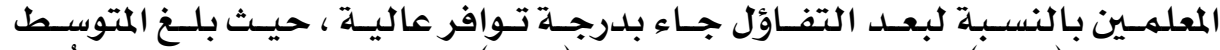

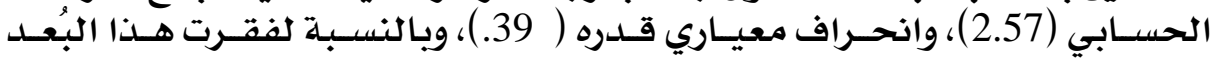

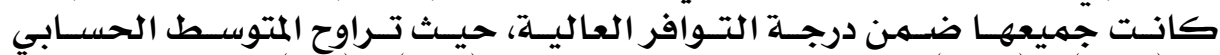

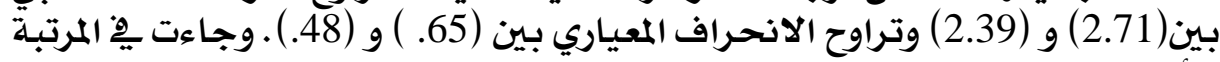

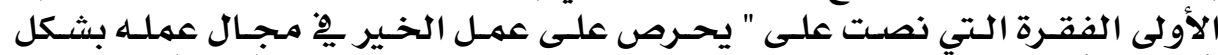

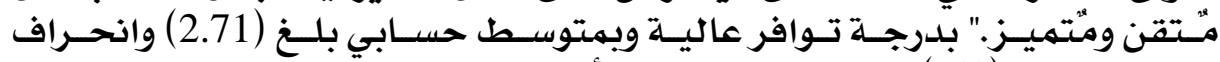

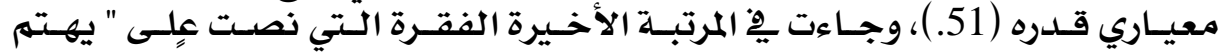

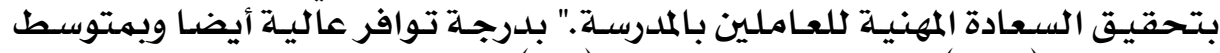

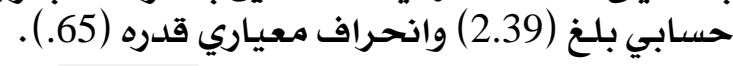




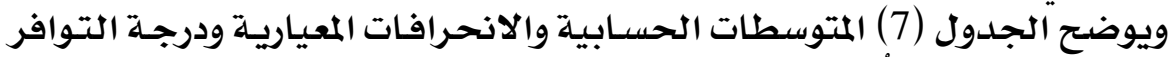
والرتبة لفقرات هذا الجدول (7) البُعد.

جدول (7): المتوسطات الحسابيت والانحرافات المعياريت ودرجت التوافر والرتبت لفقرات بُعد الثقتر

\begin{tabular}{|c|c|c|c|c|c|}
\hline 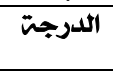 & الالانحراف & الحستوسي & الفقرة & الرتبت & i \\
\hline متوسطن & .68 & 2.32 & يثق بصورة كاملت يخ هيئت العاملين بالمدرست. & 4 & 1 \\
\hline عاليتة & .65 & 2.35 & 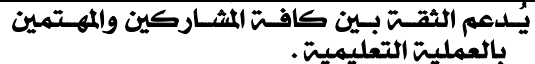 & 3 & \\
\hline عالية & .70 & 2.48 & 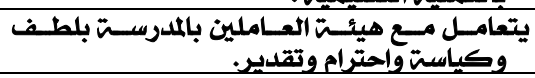 & 1 & 3 \\
\hline 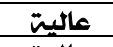 & .64 & 2.38 & تحظى قيادته بثقت وإيمان هيئت العاملين بالمدرستة. & 2 & 4 \\
\hline
\end{tabular}

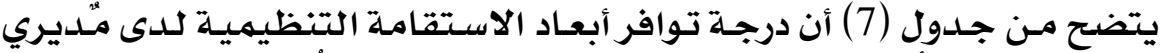

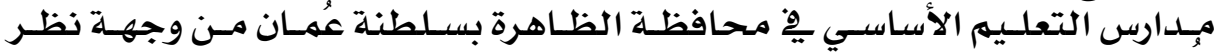

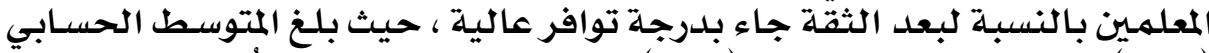

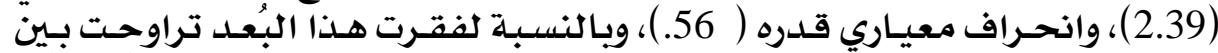

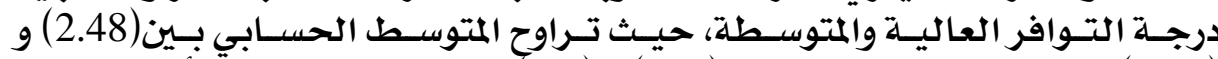

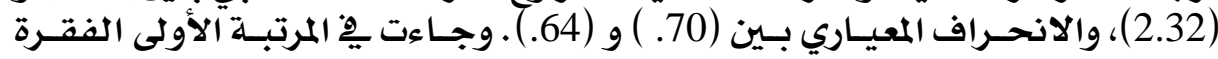

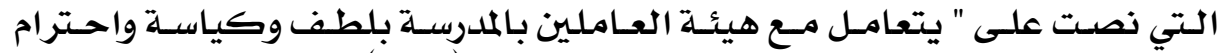

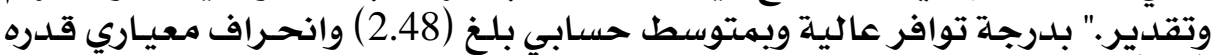

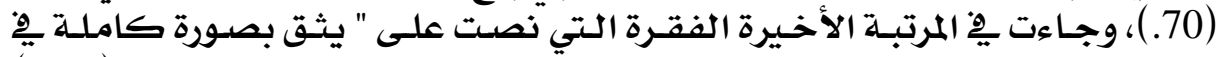

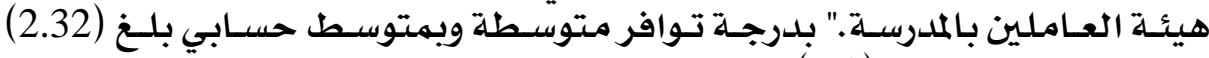

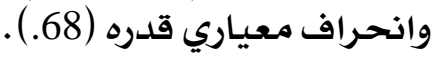

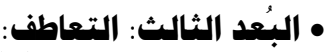

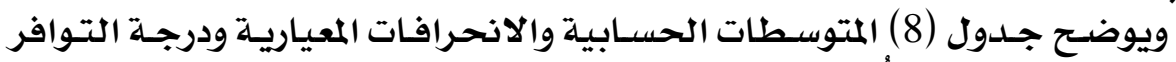
والرتبـة لفقرات هذا البُعد.

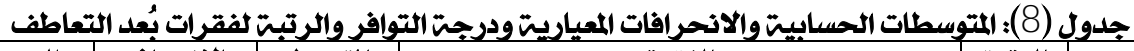

\begin{tabular}{|c|c|c|c|c|c|}
\hline الدرجت & الانحرافي & الحسابى & الفقرة & الرتبت & $p$ \\
\hline عالية & .61 & 2.61 & (ألشراركو الآخراءين مشاعرهم يو أفراحهم وأحزانهم & 1 & 1 \\
\hline عاليت & .66 & 2.45 & 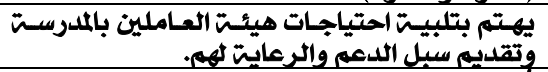 & 3 & 2 \\
\hline 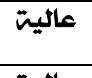 & .65 & 2.55 & 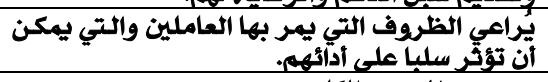 & 2 & 3 \\
\hline عاليت & .56 & 2.54 & المجموع آلكلى & & \\
\hline
\end{tabular}

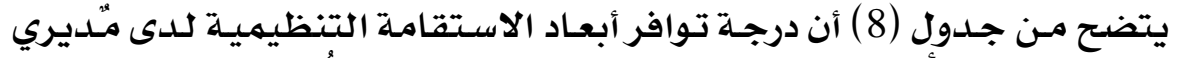

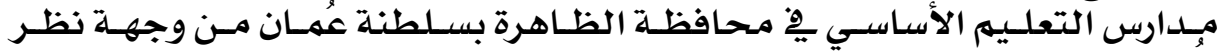

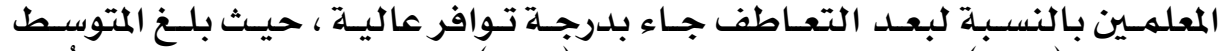

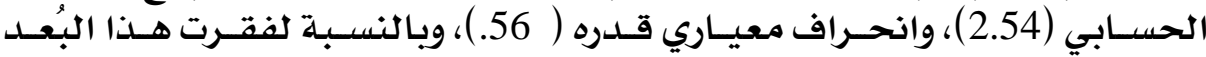

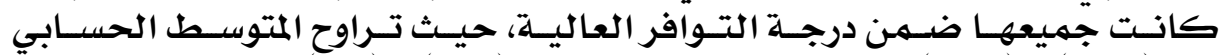

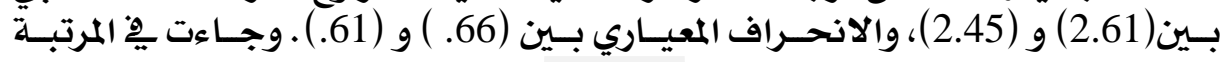




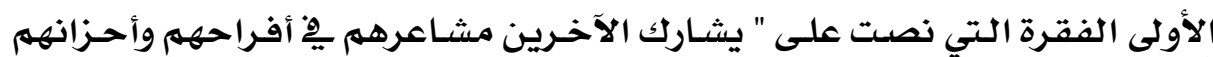

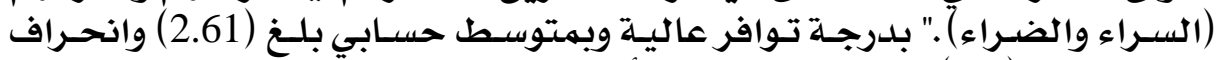

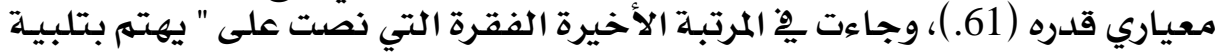

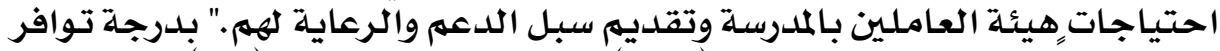

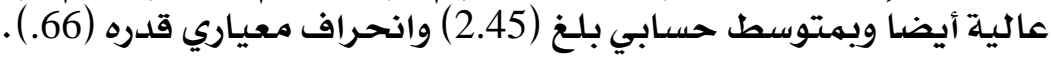

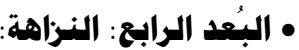

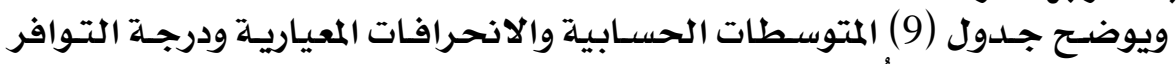
والرتبـة لفقرات هذا جـا البُعلد.

جلدول (9): المتوسطات الحسابيت والانحرافات المعياريت ودرجت الحدوث والرتبت لفقرات بُعد النزاهت

\begin{tabular}{|c|c|c|c|c|c|}
\hline 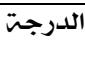 & الالعياري & الحتوسط & 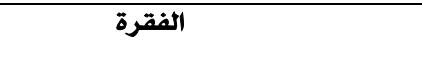 & |الرتبتة & $p$ \\
\hline عالية & .57 & 2.66 & يمتلك أعلى مستويات النزاهت بـ عمله. & 3 & \\
\hline عاليتة & .52 & 2.74 & يتسم بالفضيلت والشرف والنقاء. & 2 & 2 \\
\hline عاليتية & .53 & 2.75 & يتميز بالصدق والأمانَّ. & 1 & 3 \\
\hline عالية & .63 & 2.5 & تتسق أقواله مـع أفعاله. & 4 & 4 \\
\hline عالية & .47 & 2.68 & المجموع الكلى & & \\
\hline
\end{tabular}

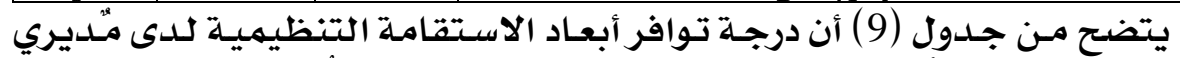

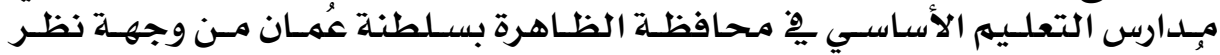

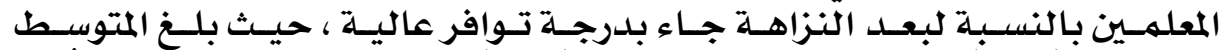

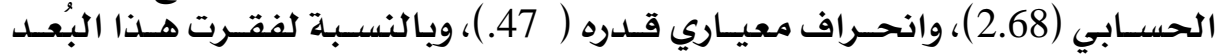

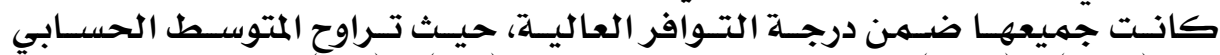

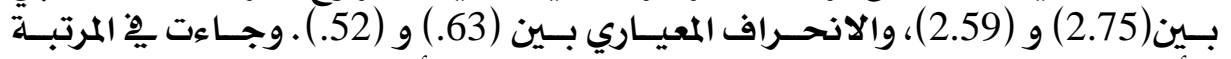

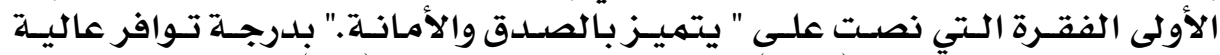

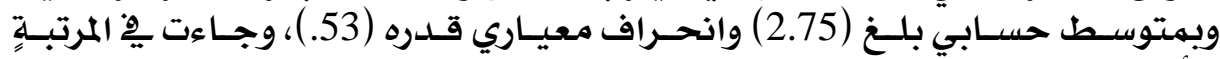

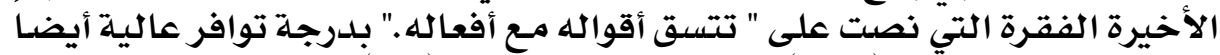

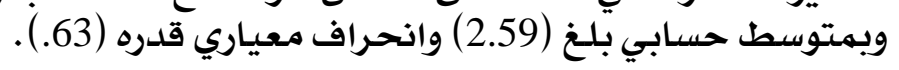

• البُعد الخاهس : التساهوح:

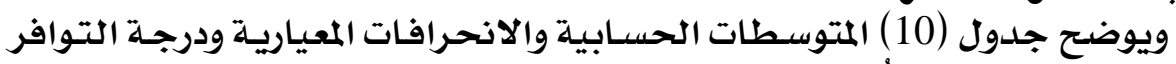
والرتبـة لفقرات هذات هذا البُعدل.

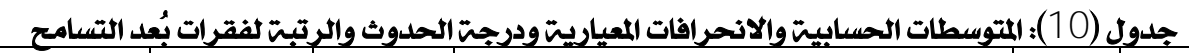

\begin{tabular}{|c|c|c|c|c|c|}
\hline الدرجة & الانحراف & الحتوسطي & الفقرة & الرتبتة & م \\
\hline متوسطت & .65 & 2.31 & يعترف باخطائه ويحاول تصحيحها بسرعت. & 3 & $\mathbf{1}$ \\
\hline عاليت & .66 & 2.46 & 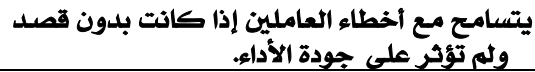 & 1 & 2 \\
\hline 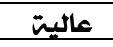 & .6 & 2.39 & يجعل من أخطائه أو اخطاء الآخرين فرص للتعلم. & 2 & 3 \\
\hline عاليتة & .57 & 2.39 & المجموع الكلي & & \\
\hline
\end{tabular}

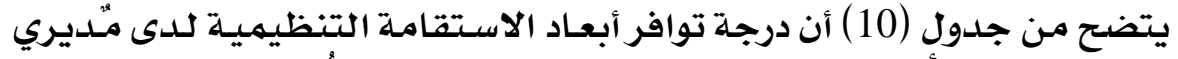

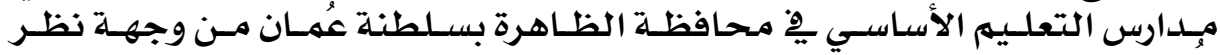

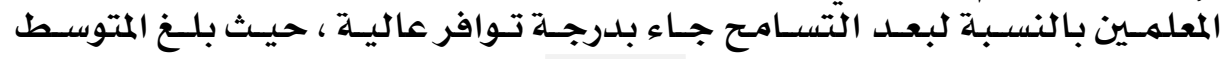




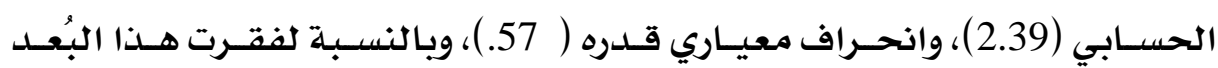

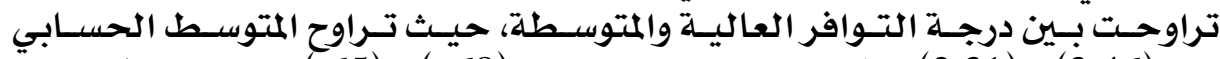

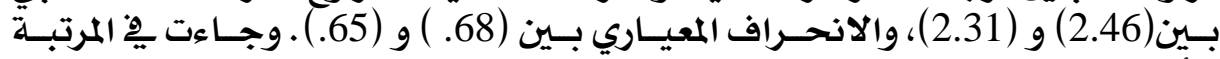

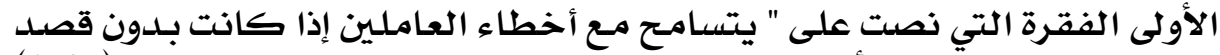

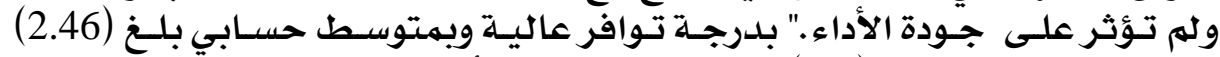

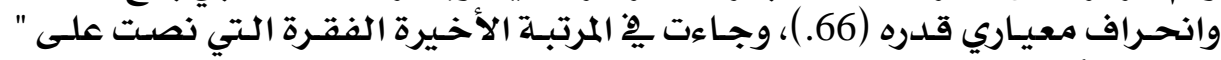

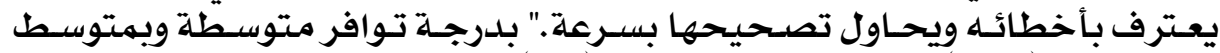

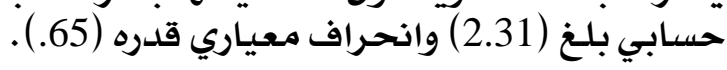

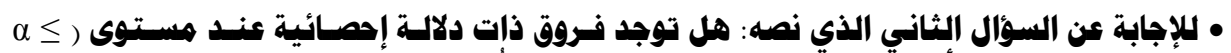

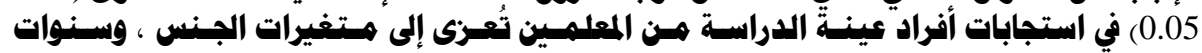

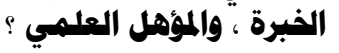

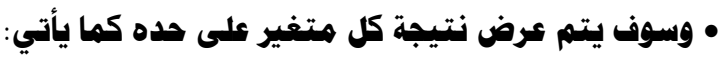

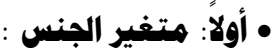

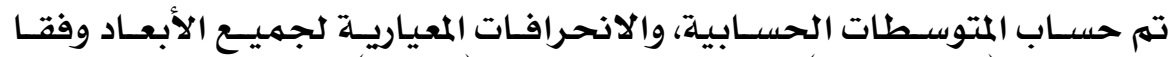

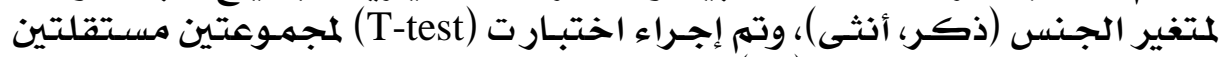

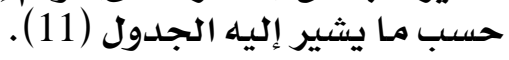

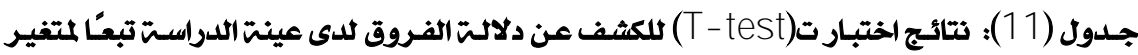

\begin{tabular}{|c|c|c|c|c|c|c|c|}
\hline \\
\hline إحصالتيائ & مستوى & قيمت (ت) & الالمعيلريراف & المتوسط & العدد & الاجتماعى & الأبعاد \\
\hline دال دصائ & .02 & 2.32 & .35 & 2.63 & $\frac{107}{96}$ & ذيكر & التفاؤل \\
\hline נו גוل & \multirow[b]{2}{*}{.01} & \multirow{2}{*}{2.57} & $\frac{.4 L}{.49}$ & 2.48 & 107 & ذذكر & \multirow[b]{2}{*}{ الثقة } \\
\hline إحصائيا & & & 61 & 2.28 & 96 & أنثى & \\
\hline دال & \multirow{2}{*}{.00} & \multirow{2}{*}{4.28} & .43 & 2.69 & 107 & ذكر & \multirow{2}{*}{ التعاطف } \\
\hline إحصائيا & & & .63 & 2.36 & 96 & أثثى & \\
\hline دال & .00 & 4.24 & 31 & 2.82 & 107 & ذكر & \multirow{2}{*}{ النزاهن } \\
\hline إحصائيا & \multirow{3}{*}{.00} & \multirow{3}{*}{3.35} & .58 & 2.54 & 96 & أثثى & \\
\hline دال & & & $\frac{49}{62}$ & $\frac{2.51}{2.5}$ & 107 & ذکكر & \multirow{2}{*}{ التسامح } \\
\hline & & & .62 & 2.25 & 96 & أنثى & \\
\hline
\end{tabular}

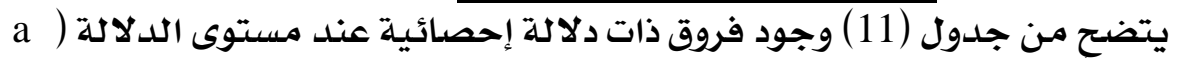

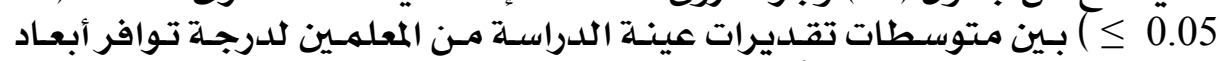

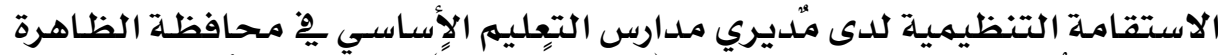

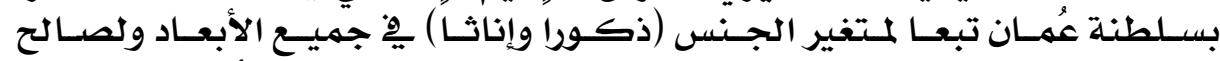

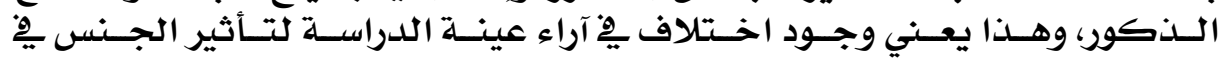

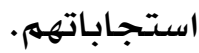

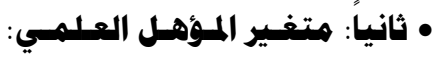

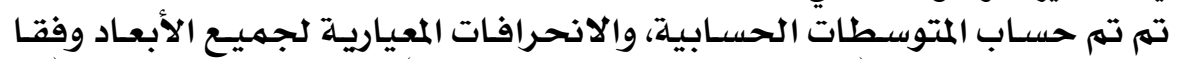

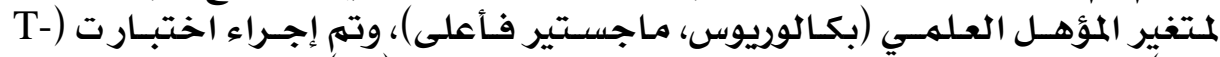
(test 


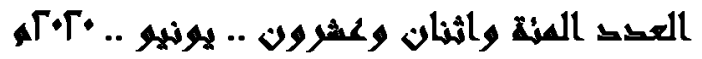

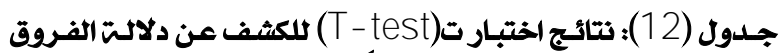

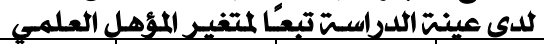

\begin{tabular}{|c|c|c|c|c|c|c|c|}
\hline 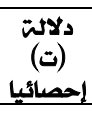 & مستوى & قيمت (ت) & المعياري & المتوسط & العدد & المؤهل & الأبعاد \\
\hline إخصيرئيا & .70 & .38 & .39 & $\begin{array}{l}2.57 \\
2.54 \\
\end{array}$ & $\begin{array}{c}182 \\
21 \\
\end{array}$ & ماجستير فاعلى & التفاؤل \\
\hline غير إحيأ & .97 & .04 & $\begin{array}{l}.56 \\
.55 \\
\end{array}$ & $\begin{array}{l}2.39 \\
2.38\end{array}$ & $\begin{array}{c}182 \\
21\end{array}$ & ماجستير فاعلى & الثقتة \\
\hline غير دالي & .87 & -.16 & $\begin{array}{l}.55 \\
.64 \\
\end{array}$ & $\begin{array}{l}2.53 \\
2.56\end{array}$ & $\begin{array}{c}\frac{182}{21} \\
\end{array}$ & ماجستير فاعلى & التعاطف \\
\hline إخصائيا & .95 & - & $\begin{array}{l}.47 \\
.55 \\
\end{array}$ & $\begin{array}{l}2.68 \\
2.69 \\
\end{array}$ & $\begin{array}{c}182 \\
21 \\
\end{array}$ & ماجستير فاعلى بكالميس & النزاهت \\
\hline غير إحيال & .56 & .58 & $\begin{array}{l}.55 \\
.70\end{array}$ & $\begin{array}{l}2.39 \\
2.32 \\
\end{array}$ & $\begin{array}{c}182 \\
21\end{array}$ & ماجستير فأعلى & التسامح \\
\hline
\end{tabular}

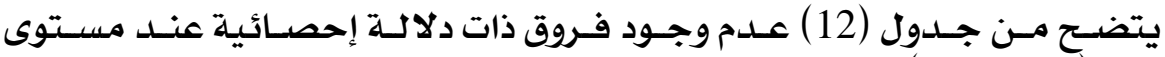

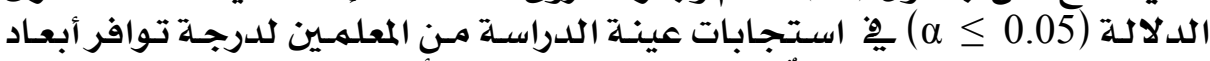

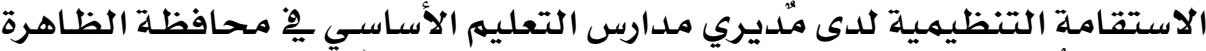

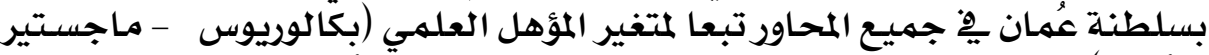

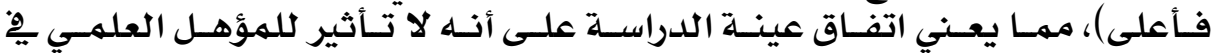

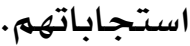

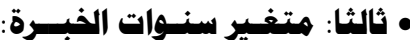

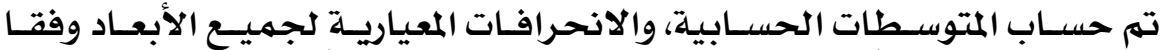

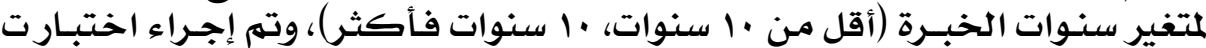
(T-test)

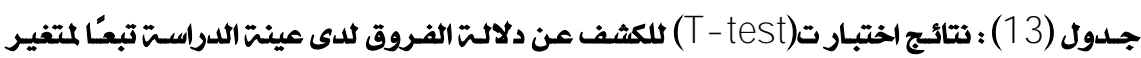
سنوات الخبرة

\begin{tabular}{|c|c|c|c|c|c|c|c|}
\hline دلالمة (ت)يا & مستوى الدلائ & قيمت (ت) & الانحراف المعياري & المتوسط & العلدد & المؤهل & الأبعاد \\
\hline \multirow{2}{*}{ فير دآل } & \multirow{2}{*}{.37} & \multirow{2}{*}{.91} & .34 & 2.61 & 50 & أقل من ·1 سنوات & \multirow[b]{2}{*}{ التفاؤل } \\
\hline & & & .41 & 2.56 & 153 & •ا سنوات فاكثر & \\
\hline \multirow{2}{*}{ فير دالي } & \multirow{2}{*}{.16} & \multirow{2}{*}{-1.40} & .56 & 2.29 & 50 & آقلل من ·1 سنوات & \multirow{2}{*}{ الثقة } \\
\hline & & & .55 & 2.42 & 153 & •ا سنوات فاكثر & \\
\hline \multirow{2}{*}{ فير دالي } & \multirow{2}{*}{.16} & \multirow{2}{*}{-1.42} & .58 & 2.44 & 50 & أقل من •ا سنوات & \multirow[b]{2}{*}{ التعاطف } \\
\hline & & & .55 & 2.57 & 153 & •ا سنوات فاكثر & \\
\hline \multirow{2}{*}{ غير دالي } & \multirow{2}{*}{.61} & \multirow{2}{*}{-.51} & .47 & 2.66 & 50 & آلقل من ·1 سنوات & \multirow[b]{2}{*}{ النزاهت } \\
\hline & & & .48 & 2.69 & 153 & •ا سنوات فاكثر & \\
\hline \multirow{2}{*}{ غير دال } & \multirow{2}{*}{.64} & \multirow{2}{*}{-.47} & .53 & 2.35 & 50 & آقل من ·1 سنوات & \multirow{2}{*}{ التسامح } \\
\hline & & & .58 & 2.40 & 153 & •ا سنوات فاكثر & \\
\hline
\end{tabular}

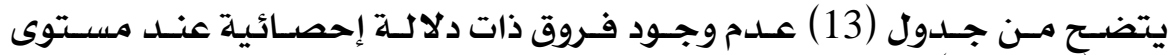

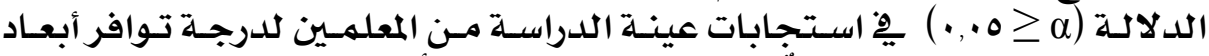

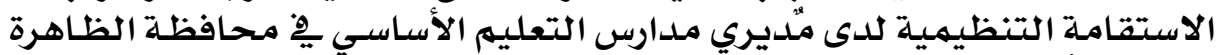

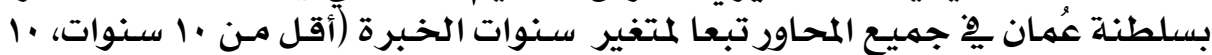

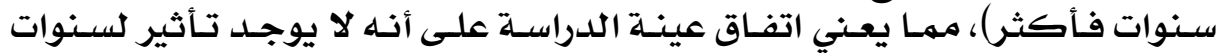

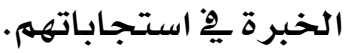




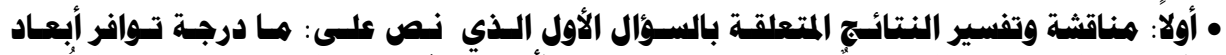

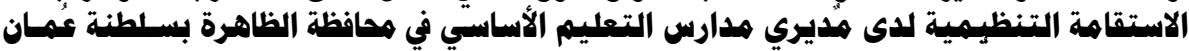

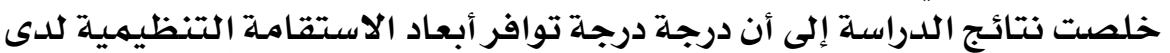

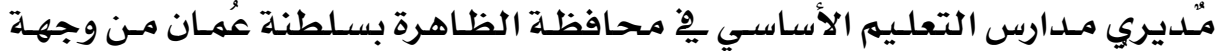

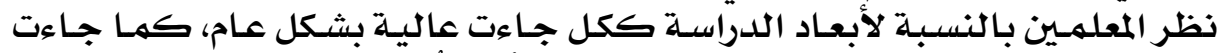

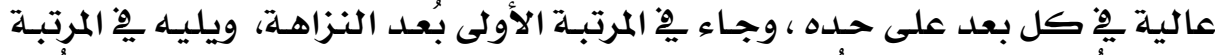

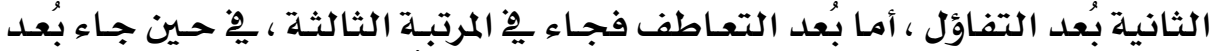

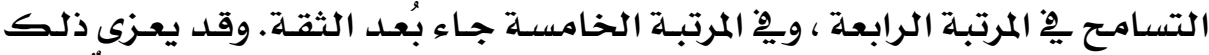

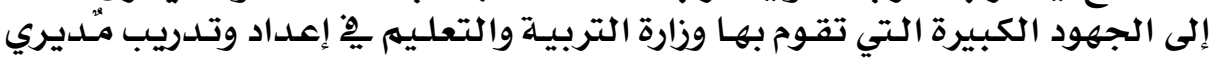

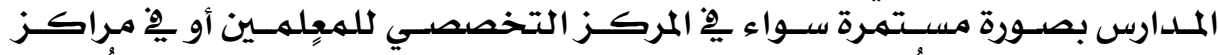

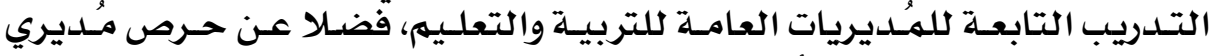

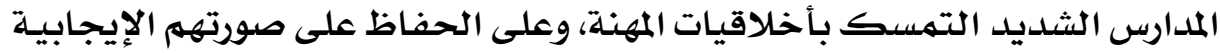

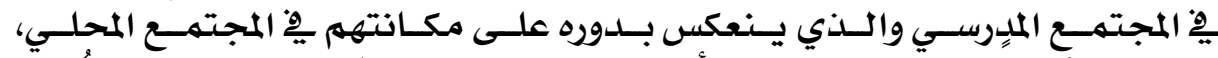

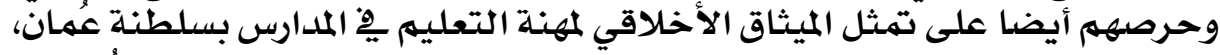

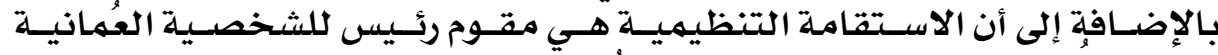

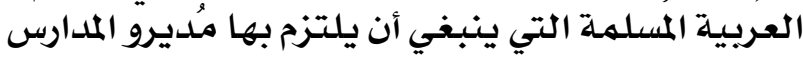

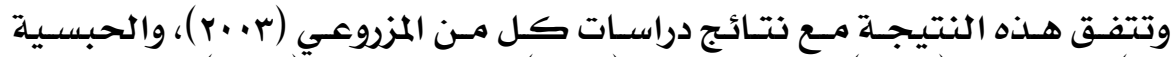

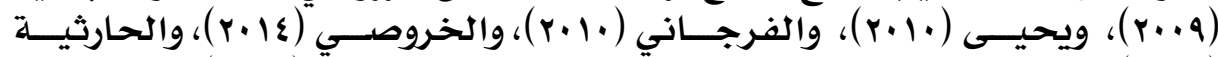

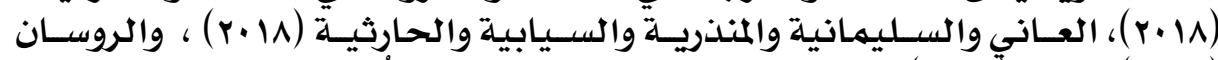

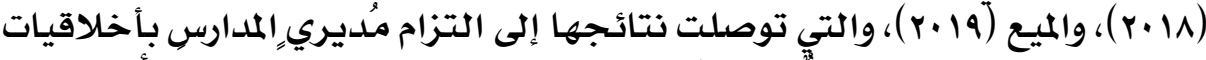

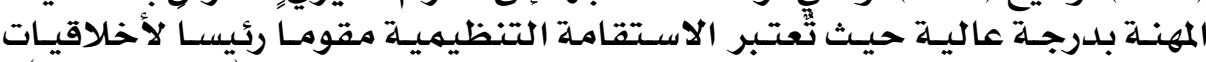

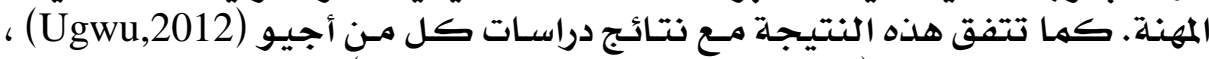

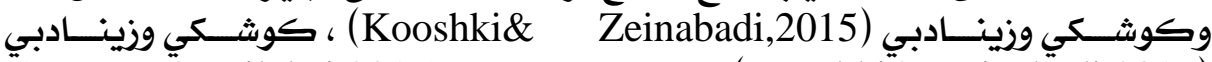

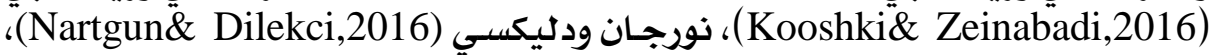

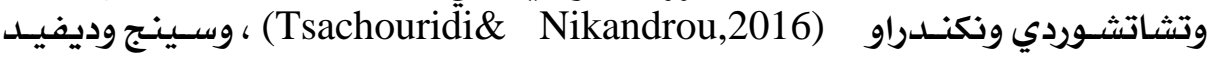

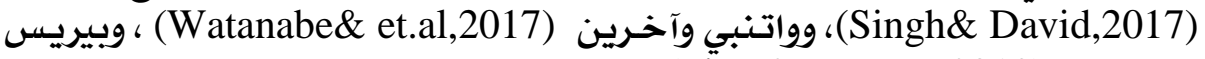

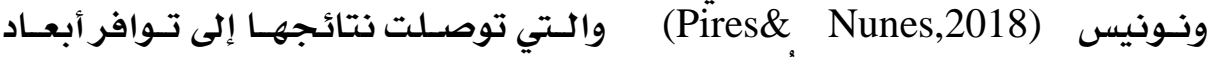

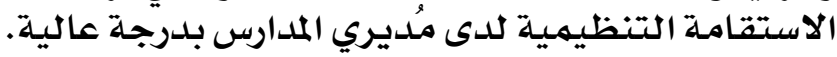

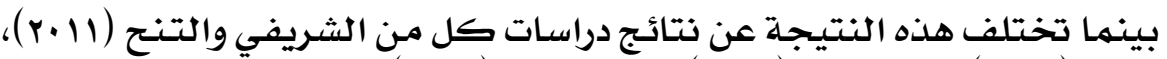

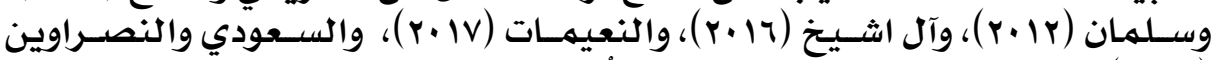

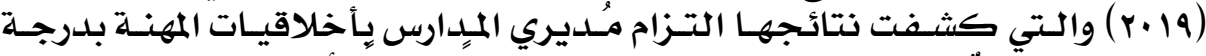

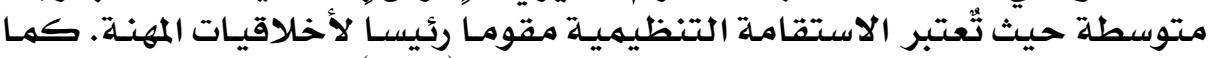

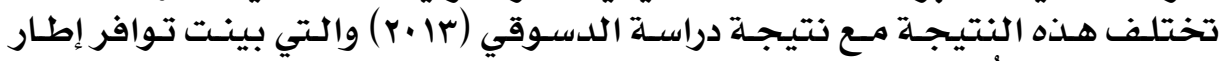

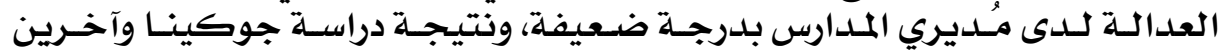


(Gukiina\& et.al,2019)

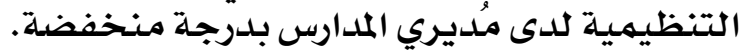

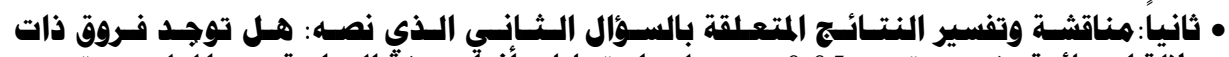

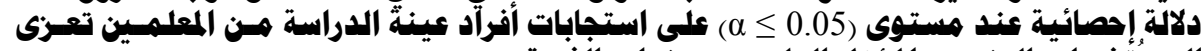

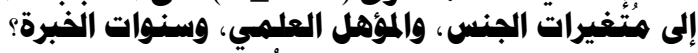

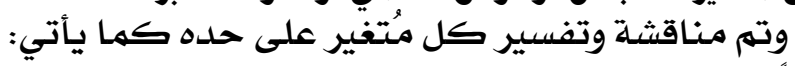

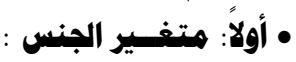

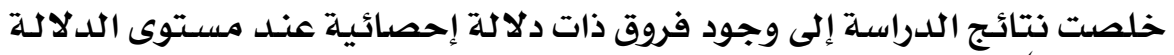

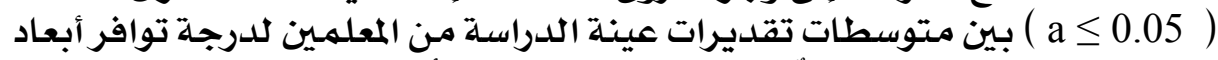

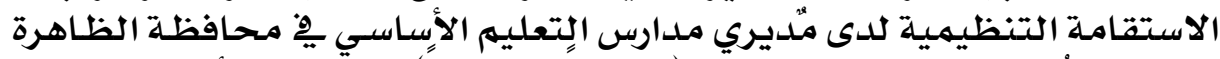

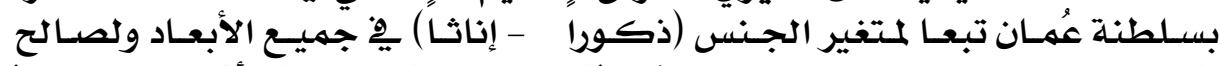

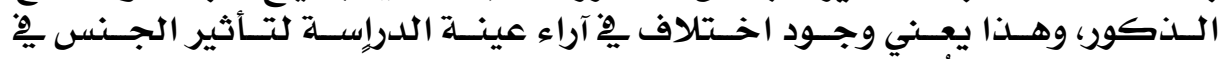

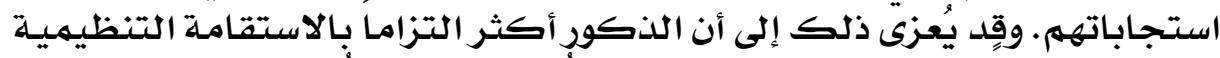

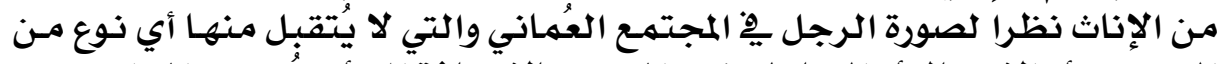

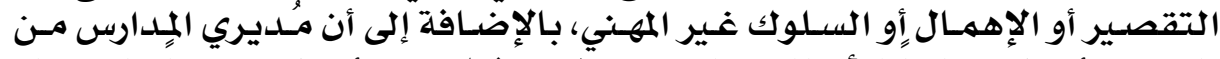

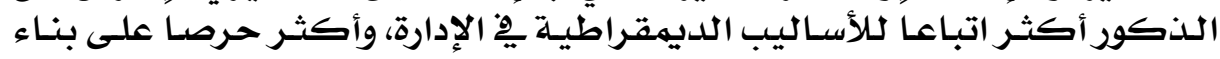

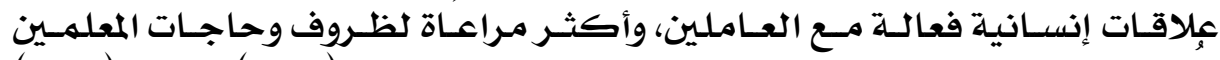

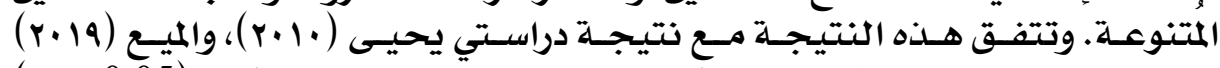

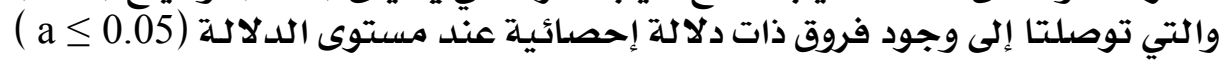

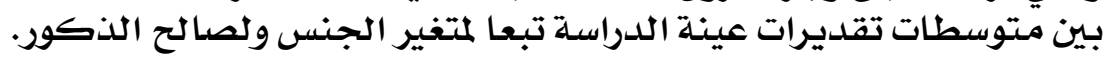

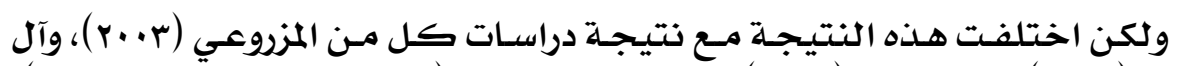

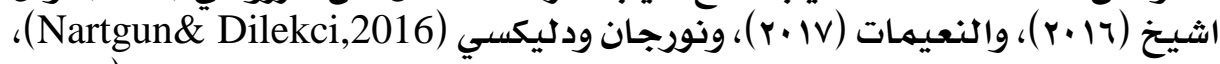
a

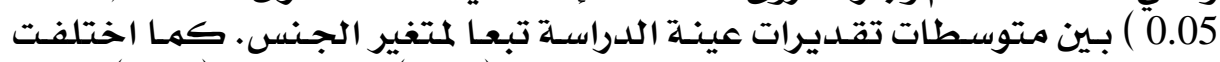

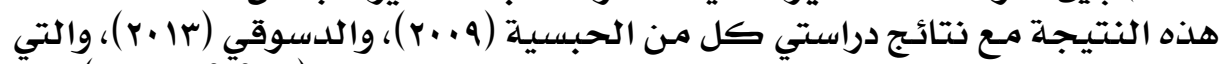

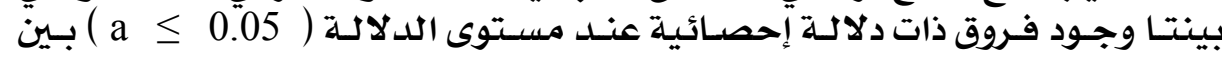

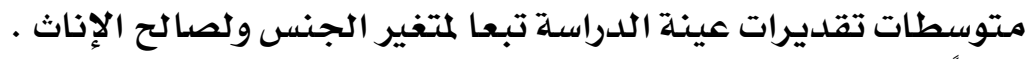

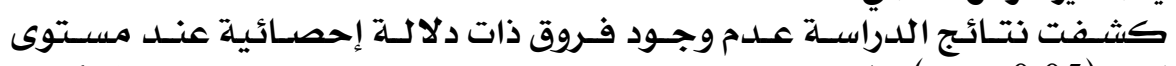

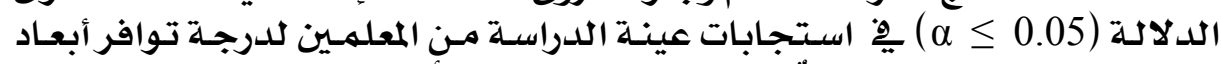

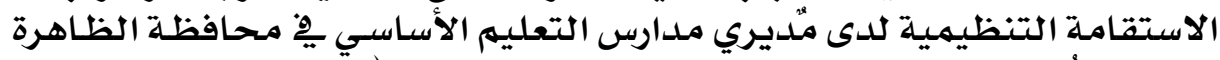

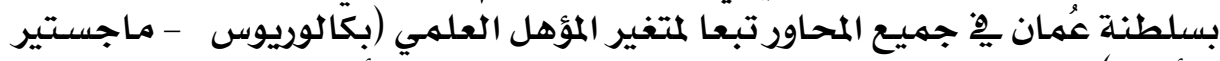

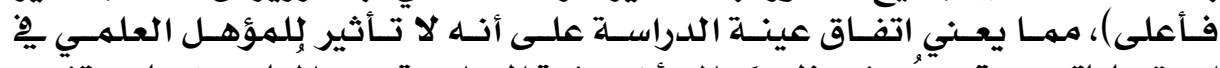

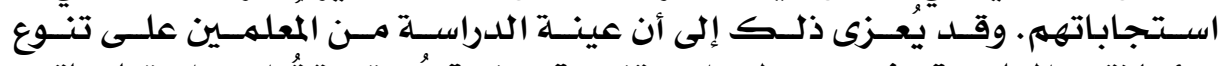

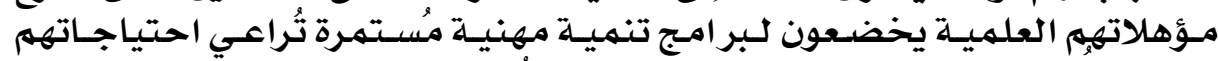

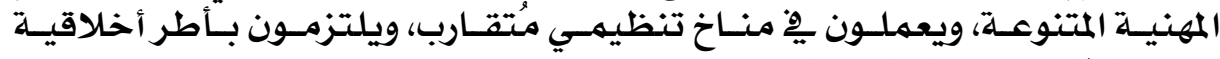
توجهها فلسفة وسياسات تعليمية واحسية واحدة. 


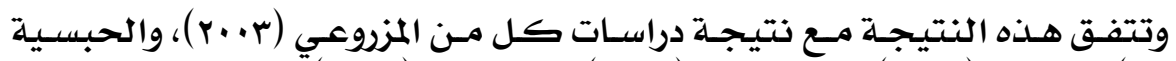

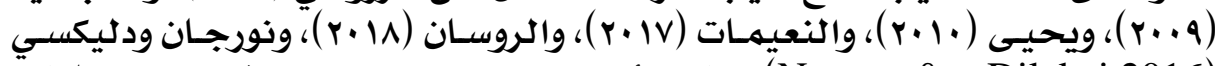

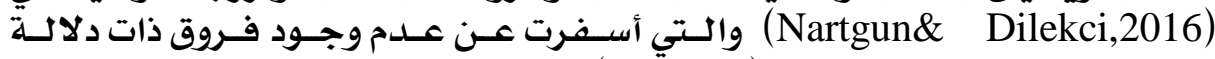

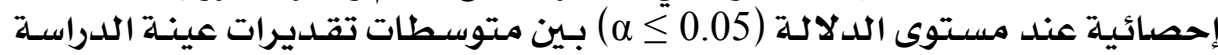
تبعا لمتغير المؤهل العلهي.

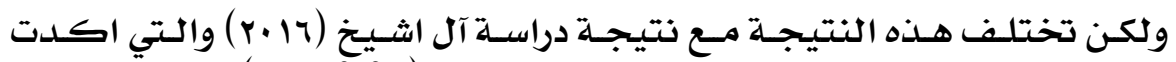

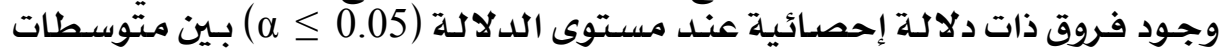

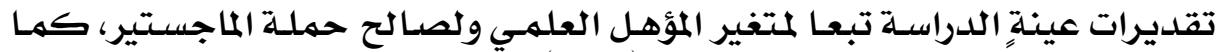

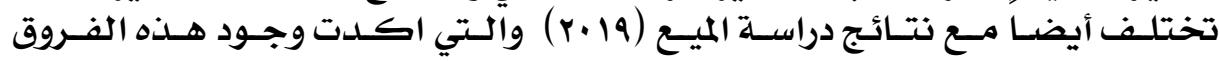
ولصالح المؤهل أقل من جـامعي.

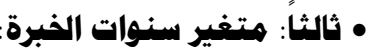

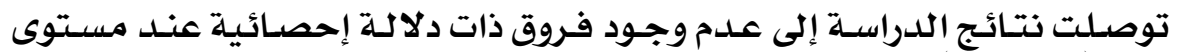

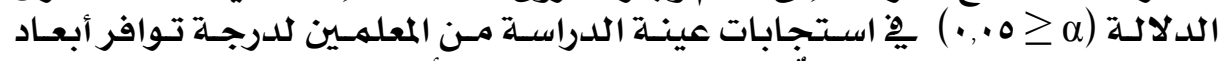

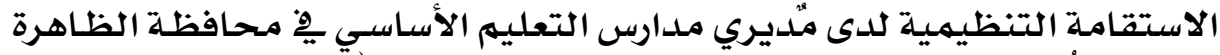

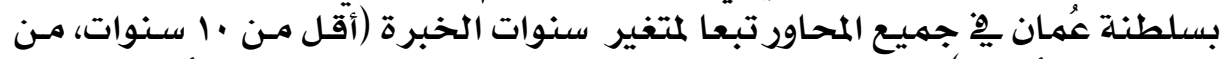

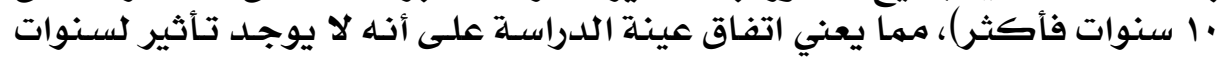

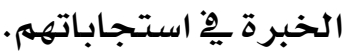

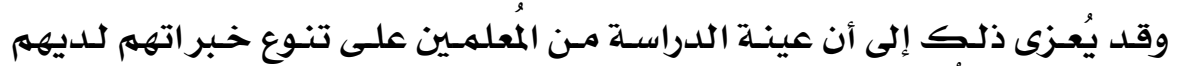

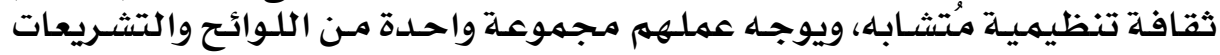
والقوانين والقرارات الوزارية.

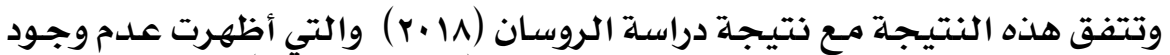

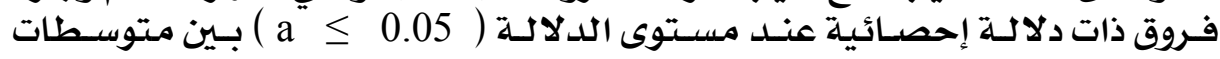

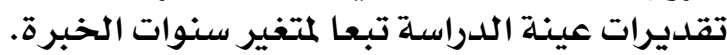

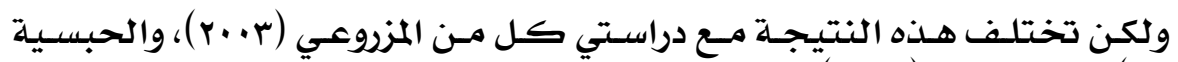

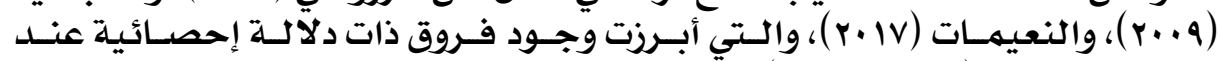

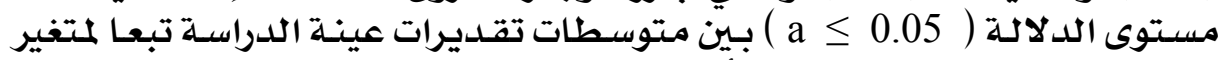

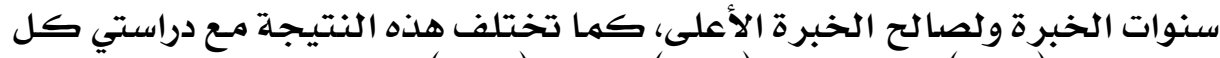

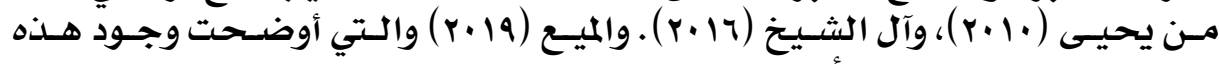

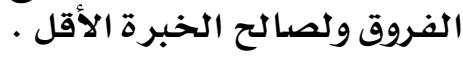

\section{• ت توصيات الدراسة:}

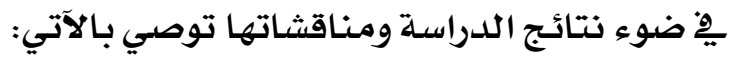

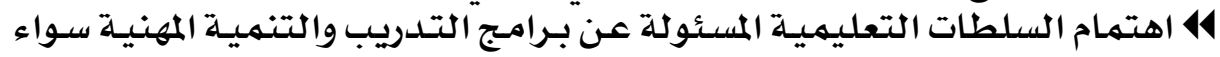

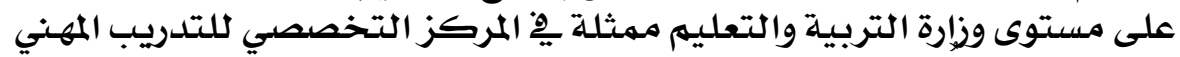

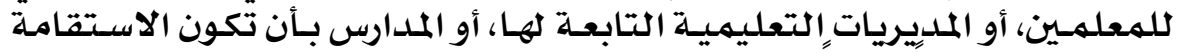

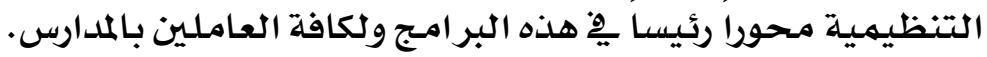

\section{ror}




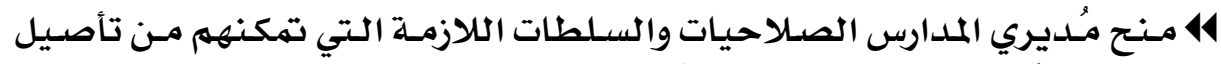

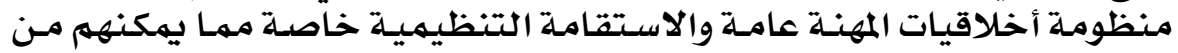

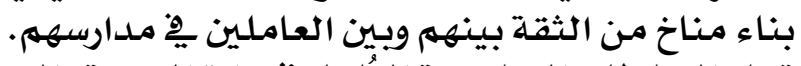

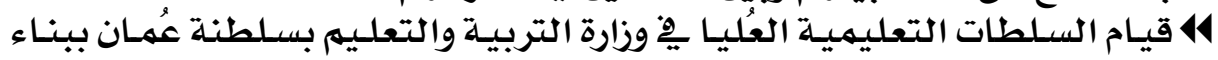

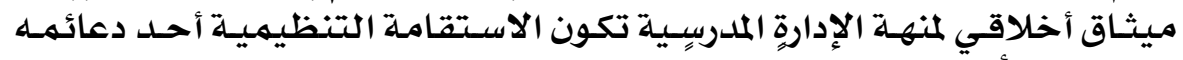

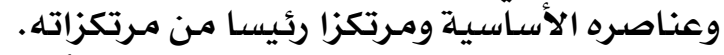

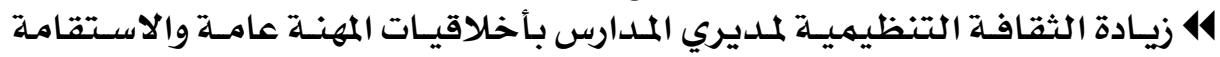

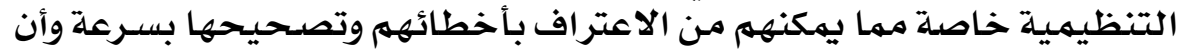

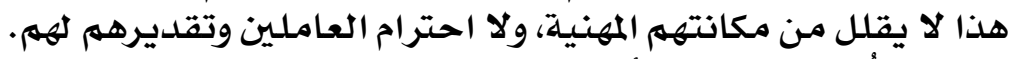

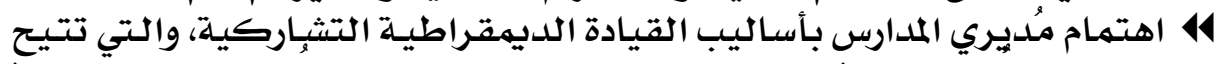

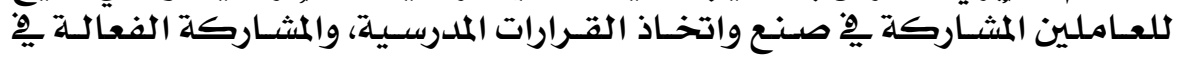

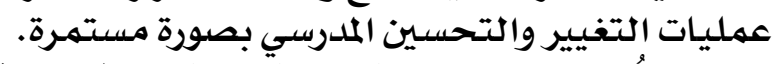

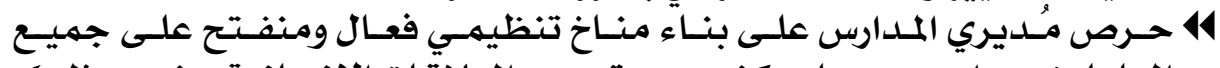

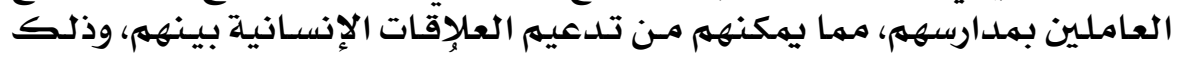

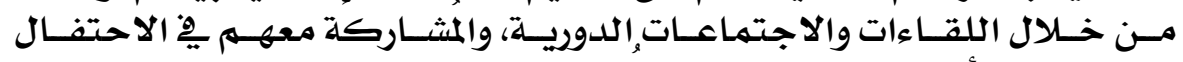

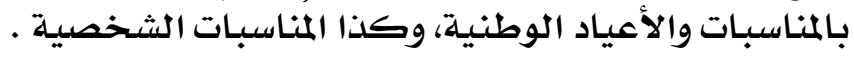

\section{• مهراجع الدراستة:

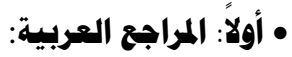

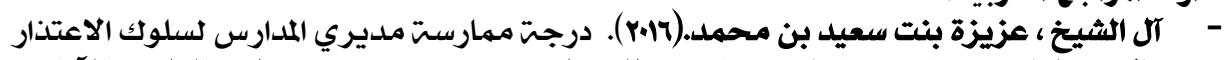

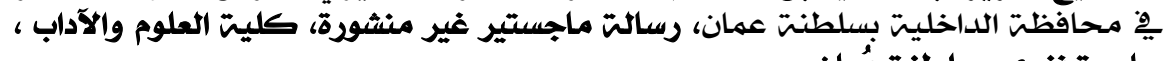

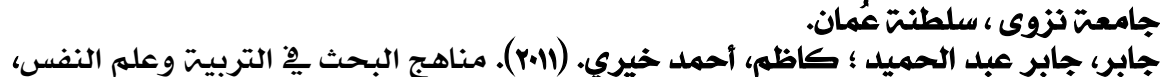
الكويت: دابر الزهراء.

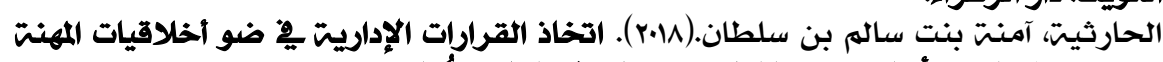

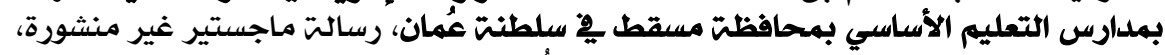

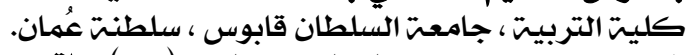

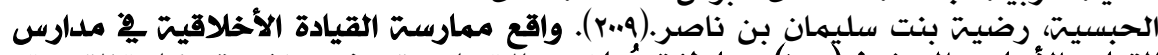

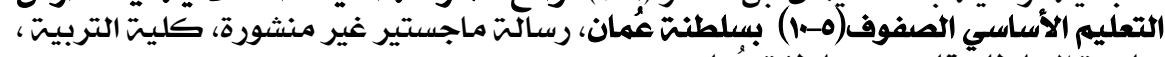

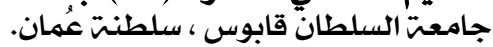

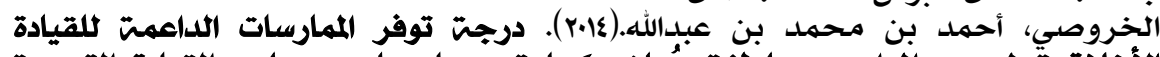

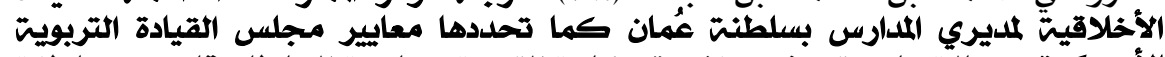

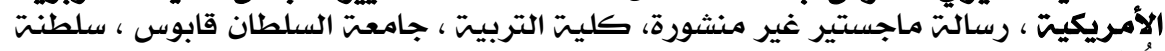
عُمان.

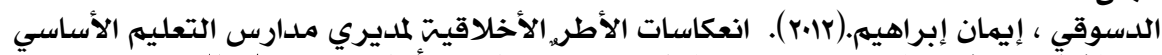

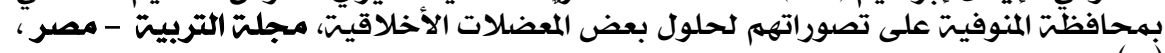

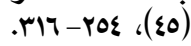

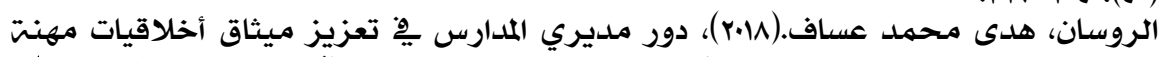

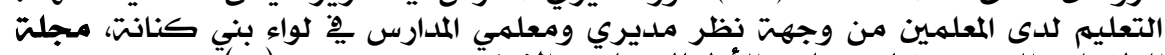

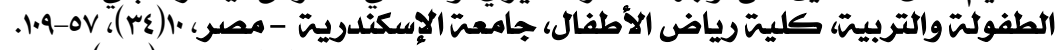

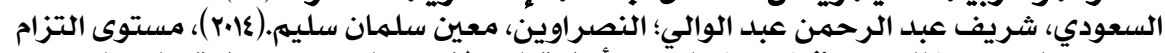

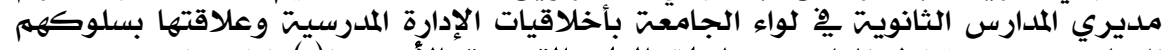

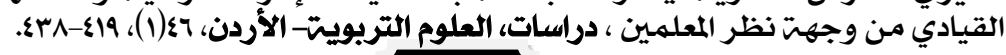

\section{$\boldsymbol{r} \odot \boldsymbol{\mu}$}

دراسات عربية في التربية وعلم النفس (ASEP) 


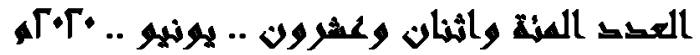

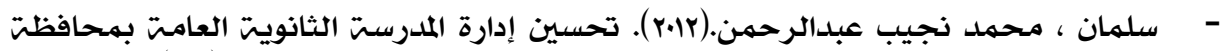

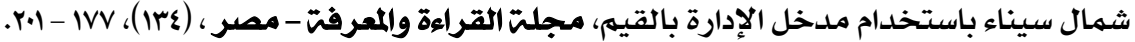

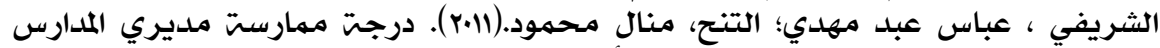

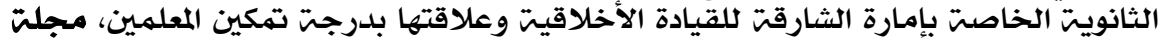

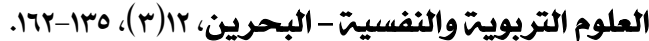

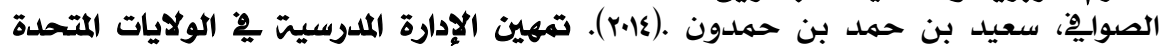

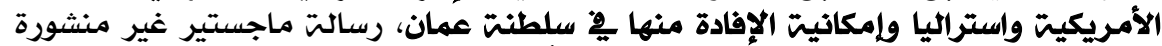

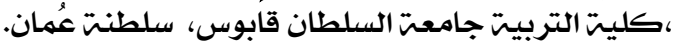

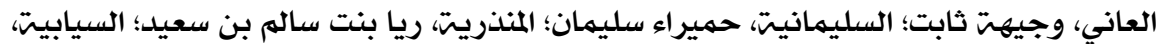

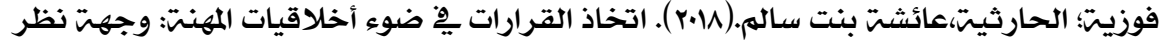

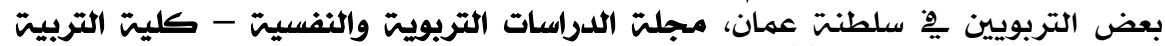

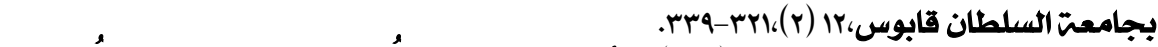

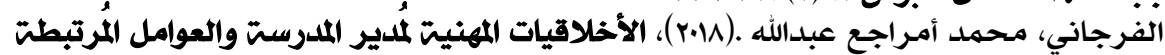

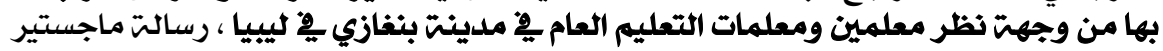

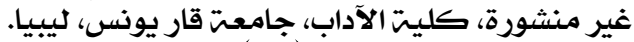

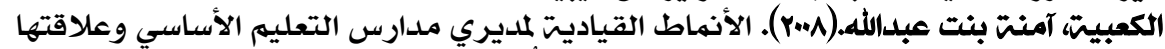

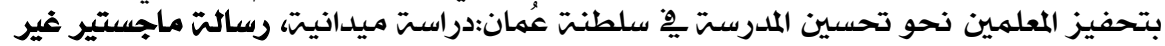

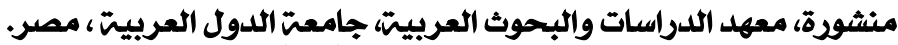

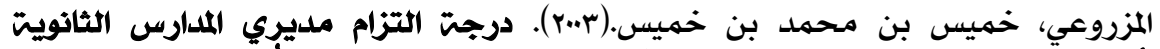

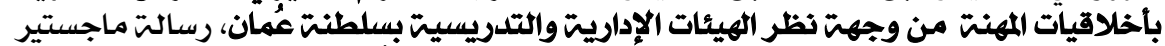

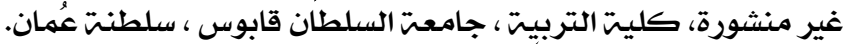

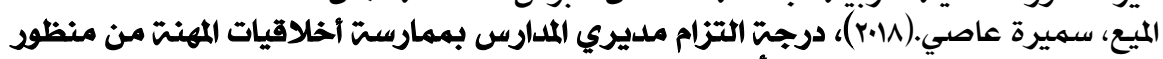

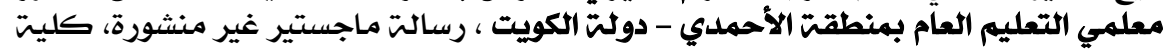

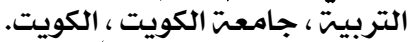

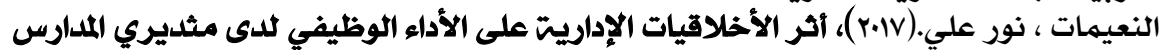

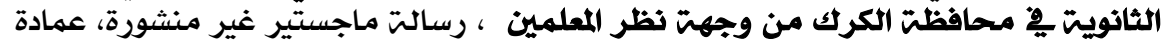

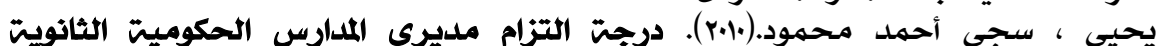

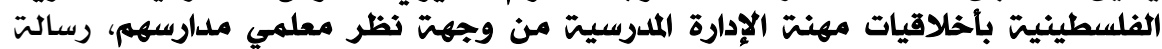

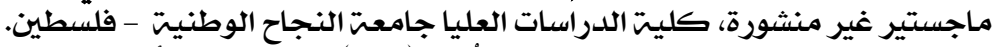

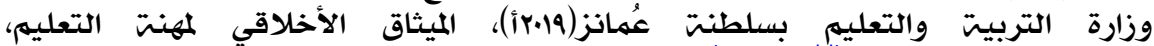
(19/11/1،/https://home. moe.gov.om

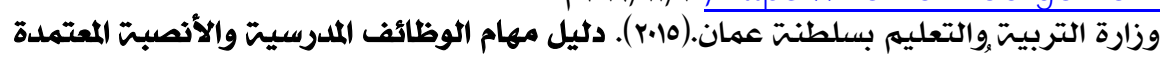

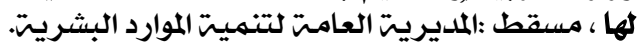

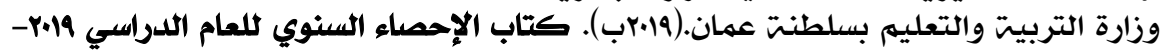

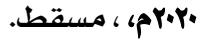

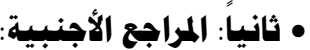
- Abedi,Sedighe; Eslami,Hoseyn; Amrolahi,Nahid.(2014). The Role of Organizational Virtuousness on The Organizational Commitment of Employees (Case Study: Islamic Azad University), Interdisciplinary Journal of Contemporary Research in Business, 5 (10), 118-130.

- Asad,Humaira; Naseem,Rabia; Faiz,Rafia.(2017).Mediating effect of Ethical Climate between Organizational Virtuousness and Job 


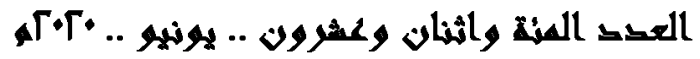

Satisfaction, Pakistan Journal of Commerce and Social Sciences, 11(1), 35-48

- Bright, David, Cameron, Kim., \& Caza, Arran. (2006). The amplifying and buffering effects of virtuousness in downsized organizations, Journal of Business Ethics, 64(3), 249-269.

- Cameron,Kim.(2003). Organizational Virtuousness and Performance,in Positive Organizational Scholarship , Cameron, Kim; Dutton ,Jane E. ; Quinn,Robert E.(EDS), San Francisco: BerrettKoehler, Chapter 4, 48-65 .

- Cameron,Kim; Bright,David; Caza,Arran .(2004). Exploring the Relationships Between Organizational Virtuousness and Performance, American Behavioral Scientist, 47(6), 1-24.

- Gukiina, Joshua . Mr.; Ntayi, Joseph M.; Balunywa, Waswa; Ahiauzu, Augustine. (2019). Organizational Virtuousness: The Customers' Perspective, African Social Science Review, 10 (1) , 106-163

- Gukiina,Joshua ; Balunywa,Waswa ; Ntayi,Joseph ; Ahiauzu, Augustine.(2017). Organizational Virtuousness: The Customers' Perspective, International Journal on Customer Relations,5 (2), 18-36.

- Gukiina,Joshua; Ntayi,Joseph; Balunywa,Waswa; Ahiauzu, Augustine.(2018). Institutional Identification and Organizational Citizenship Behaviors of Uganda Hotel Staff: The Mediation Role of Organizational Virtuousness, Singaporean Journal of Business Economics, and Management Studies, 6(2), 77-101.

- Hamrahi,Mehrdad; Najafbagy ,Reza; Musakhani ,Morteza.(2015). Factors Effecting on Promoting Organizational Virtuousness in Iran State Agencies, Indian Journal of Fundamental and Applied Life Sciences,5 (1), 4772-4779.

- Kooshki,Sara; Zeinabadi,Hassanreza.(2015). An Investigation Into the Role of Organizational Virtuousness in the Job Attitudes of Teachers, Jurnal UMP Social Sciences and Technology Management,3 (1), 563570.

- Kooshki,Sara; Zeinabadi,Hassanreza.(2015). The Role of Organizational Virtuousness in Organizational Citizenship Behavior of Teachers: The Test of Direct and Indirect Effect Through Job Satisfaction Mediating, International Review, (1-2), 7-21.

- Kooshki,Sara; Zeinabadi,Hassanreza.(2016). Organizational Virtuousness in Schools: A Review of Factor Structure of a Tool in Secondary Schools, Journal of Administrative Management, Education and Training,12 (2), 60-69.

- Malik,Sania ; Naeem,Ramsha.(2016). Organizational Virtuousness, Perceived Organizational Support and Organizational Citizenship Behavior: A Mediation Framework, Journal of Behavioural Sciences, 26(1), 113-129. 
- Meyer, Marcel.(2018). The Evolution and Challenges of the Concept of Organizational Virtuousness in Positive Organizational Scholarship, Journal of Business Ethics, (153), 245-264.

- Nartgun,Senay ; Dilekci, Umit.(2016). Teacher Views on Administrators' Leadership Styles and Level of Organizational Virtuousness , Anthropologist,24 (1), 363-372.

- Nikandrou,Irene; Tsachouridi,Irene. (2015). Towards a better understanding of the buffering effects of organizational virtuousness' perceptions on employee outcomes, Management Decision, 53(8), . $1823-1842$.

- Pereira, Sandra.(2014). Changing Organization's in the Public Sector: Individual and Organizational Strategies Towards Perceived Performance Improvement, Un published Doctoral Dissertation, Institute of Applied Psychology, Instituto universitário in Lisbon, Portugal.

- Pires, Maria; Nunes, Francisco . (2018). The Mediating Role of Virtuousness in Human Resource Management and Job Outcomes , Revista de Administração de Empresas , 58(4), 380-392.

- Ravaji,Marjan.(2016). The Effect of Organizational Virtuousness and Psychological Capital Role on Employees' Creativity In Tehran Water and Wastewater Company, International Journal of Scientific Management and Development, 4(12), 496-506.

- Singh,Sharda; David, Rajasekhar.(2017). Organizational Virtuousness and Work Engagement: Mediating Role of Happiness in India, Advances in Developing Human Resources, 20 (1), 3-10.

- Tsachouridi,Irene; Nikandrou,Irene.(2016). Organizational virtuousness and spontaneity: a social identity view, Personnel Review,45 (6), 1302-1322.

- Ugwu, Fabian O. (2012). Are Good Morals of Ten Reciprocated? Perceptions of Organizational Virtuousness and Optimism as Predictors of Work Engagement, Asian Journal of Social Sciences \& Humanities, 1 (3), 188-198.

- Watanabe,Remy; Uchida,Toru; Orsini,Philippe; Benton, Caroline . (2017). Organizational virtuousness and job performance in Japan: does happiness matter?, International Journal of Organizational Analysis, 25 (4), 628-646.

- Zeng,Xian.(2018). Development of Framework Linking Organizational Virtuousness and Pro-Social Rule Breaking: From the Perspective of Social Information Processing, Open Journal of Social Sciences, (6), 80-89. 